NBER WORKING PAPER SERIES

SOURCES OF GROWTH IN THE INDIAN ECONOMY

\author{
Barry Bosworth \\ Susan M. Collins \\ Arvind Virmani \\ Working Paper 12901 \\ http://www.nber.org/papers/w12901
NATIONAL BUREAU OF ECONOMIC RESEARCH
1050 Massachusetts Avenue
Cambridge, MA 02138
February 2007

The authors are respectively Senior Fellow at the Brookings Institution, Senior Fellow at Brookings and Professor of Economics at Georgetown University, and Principle Advisor, Planning Commission (former Director, ICRIER). We thank Gabriel Chodorow-Reich for expert research assistance. This paper was presented at the India Policy Forum (July 31-August 1, 2006, New Delhi) and a revised version will be published in the 2006 issue of that journal. The views expressed herein are those of the author(s) and do not necessarily reflect the views of the National Bureau of Economic Research.

(C) 2007 by Barry Bosworth, Susan M. Collins, and Arvind Virmani. All rights reserved. Short sections of text, not to exceed two paragraphs, may be quoted without explicit permission provided that full credit, including $\odot$ notice, is given to the source. 
Sources of Growth in the Indian Economy

Barry Bosworth, Susan M. Collins, and Arvind Virmani

NBER Working Paper No. 12901

February 2007

JEL No. F43,O4

\section{ABSTRACT}

This paper empirically examines India's economic growth experience during 1960-2004, focusing on the post 1973 acceleration. Careful attention is paid to data quality. The analysis focuses on two unusual dimensions of India's experience -- the concentration of growth in services production, and the modest levels of human and physical capital accumulation. A growth accounting analysis disaggregates by major sector, and highlights implications for aggregate productivity growth of the reallocation of resources out of agriculture to more productive activities in industry and services. But concerns are raised that growth in services may be overstated. India will need to broaden its current expansion to provide manufactured goods for the world market and jobs for its large pool of low-skilled workers. Increased public saving, as well as a rise in foreign saving -- particularly FDI -- could augment the rising household saving and support the increased investment necessary to sustain rapid growth.

Barry Bosworth

Senior Fellow

The Brookings Institution

1775 Massachusetts Avenue

Washington, DC 20036

bbosworth@brookings.edu
Arvind Virmani

Principal Advisor

Planning Commission

Yojana Bhawan, Sansad Marg

New Delhi 110001

virmani@nic.in

Susan M. Collins

Professor of Economics, Georgetown University \&

Senior Fellow, The Brookings Institution

1775 Massachusetts Avenue, N.W.

Washington, D.C. 20036

and NBER

scollins@brookings.edu 
Preliminary -July 15, 2006

\title{
Sources of Growth in the Indian Economy
}

\author{
by
Barry Bosworth, Susan M. Collins, and Arvind Virmani

Recent years have witnessed a growing optimism about the potential for Indian economic growth. In part, this is fueled by the example of strong sustained growth in China, raising the obvious question of why India cannot do as well. However, the optimism also reflects the fact that India's growth has accelerated over the past two decades. And while its growth rate remains well below that of China, this favorable performance contrasts with the slowing of growth in other regions. It has also enabled the emergence of a significant middle class in India. Interestingly, India's economic performance has differed from that of China and other parts of Asia in at least two dimensions. First, India's success has not been based on strong growth in the manufacturing sector and in exports. Instead, it has reflected very rapid expansion of service-producing industries. Second, it has been associated with relatively modest levels of investment. Even incorporating recent data revisions, India's physical capital accumulation has not been impressive. And despite substantial increases in the number of Indians attaining higher education, illiteracy rates remain high.

In this paper, we build on a growth accounting framework to empirically examine these dimensions of India's recent growth. Where has the growth been concentrated, as among agriculture, industry, and the service-producing sectors? What are the major contributors to that growth: increased employment, capital per worker, educational attainment, or improvements in the basic efficiency of resource use (total factor productivity)? We also examine each of the features noted above that distinguish India's recent performance. Thus, we are particularly interested in the sources of growth in the service-producing industries. Is it sustainable or should India place greater emphasis on 
the manufacturing sector and the promotion of rapid growth in export markets? We also emphasize the roles of both physical and human capital accumulation. Throughout the analysis, we are particularly concerned about the quality of the available statistical data, and the influence this may have on our conclusions.

There is already an extensive empirical literature - often using growth accounts that examines these and other aspects of India's economic growth. Many of the studies address one or more of the following topics. First, a number of analysts have focused on characterizing India's economic performance at the most aggregate level. While there is agreement that growth did indeed improve during the past quarter century, researchers have reached varying conclusions on some issues such as the timing and precise magnitude of this acceleration, and the relative importance of changes in domestic policy. For example, Virmani (1997), Rodrik and Subramanian (2005) and Kohli (2006a and b) point out that growth initially accelerated during the $1980 \mathrm{~s}$, predating the reforms that followed the crisis of the early 1990s. Within this context, Rodrik-Subramanian and Kohli both stress the role of what they term "pro-business" reforms that began in the early 1980s. In contrast, Srinivasan (2003b) and Panagyria (2004) argue that, prior to the more substantial liberalizations that emerged in the 1990s, growth was built largely on unsustainable increases in public expenditures and excessive foreign borrowing that culminated in the balance of payments crisis of 1991. There are on-going discussions over the extent to which the current growth can be maintained and various means by which it might be increased.

Second, analysts have examined the behavior of particular output sectors. A number of authors have studied productivity in manufacturing - reaching a wide range of conflicting conclusions. However, as explained in detail by Goldar and Mitra (2002), differences in the findings can be attributed to a variety of measurement issues, such as the use of singe versus double deflation to construct estimates of real growth in manufacturing value added. Goldar (2004) provides a careful recent update showing that TFP growth in manufacturing appears to have slowed in the post reform period - raising additional puzzles discussed below. (These two papers provide additional references to the relevant work.) However, due to difficulties in measuring employment within individual industries, our analysis focuses primarily on the broader industrial sector. The 
studies that focus on India's services sector (many of which discuss the issue of sustainability), and those that discuss agriculture, are discussed in the body of the paper.

Given the large body of prior research, many of the results to be discussed below are already well-known to those in the field. None-the-less, this paper seeks to make a contribution to that literature in a variety of ways. In particular, the growth accounting framework, combined with our emphasis on data issues, pulls together concerns that have typically been treated separately, and in some cases, raise implications that do not appear to have been consistently recognized. Our updated growth accounts incorporate recent data revisions, some of which are quite large. They also provide new estimates for the contributions to overall growth of labor productivity growth within the major economic sectors versus the gains from reallocation of labor and capital among the factors. Furthermore, we have examined a variety of additional data in our analysis of the role of capital accumulation - providing estimates of the returns to schooling for human capital, and reporting on trends in sectoral saving and investment, for physical capital.

Thus, this paper is comprised of four remaining sections. The next section details the construction of growth accounts for India, with considerable attention paid to the quality of the underlying data. The following section presents and discusses the results. Section three examines a range of issues related to the role of capital accumulation in India's growth experience. It focuses first on human capital and then turns to an analysis of investment and saving behavior in India. Drawing from the preceding analyses, the final section discusses implications for Indian economic growth, going forward.

We argue that the emphasis on business services as the driving force behind the expansion of the Indian economy is frequently overstated. Despite its extraordinary growth, the industry comprises only a small share of India's GDP and overall employment. Instead, high rates of total factor productivity (TFP) growth in the overall services sector, which includes such industries as trade, transportation and education where we would not expect to observe rapid TFP growth, raise concerns that growth of the sector may be overstated in the statistics. In addition, business services provide jobs primarily for the relatively small proportion of the workforce that is highly educated. We find some evidence that the current emphasis on high-skill services is already encountering some shortages -- a bidding up of the relative wage rate for secondary and 
university-level graduates. In any case, the expansion is not creating adequate job growth for the bulk of the Indian population that is not particularly well-educated.

Thus, India would benefit from broadening the base of the current expansion by promoting programs that would increase India's attractiveness as a source of manufactured goods for the world market. The growth of the manufacturing sector would provide a strong match for the skills of the Indian workforce. This would require more urgent attention to improving the infrastructure in the areas of energy reliability, transportation and port facilities.

India also faces significant challenges in the quality of the educational system. As we illustrate, the Indian workforce is not particularly well-educated. Illiteracy rates are high by international standards, even among the young, and we find evidence of shortages among the group of highly-educated workers (university graduates) who have done so well in recent years. This suggests that India needs to expand the supply of welleducated workers at the same time that it increases the demand for workers with more modest skills.

Furthermore, we conclude that the supply of private saving in India is adequate to support a significantly higher rate of growth in future years. From the perspective of physical capital formation, the problems are more concentrated in the extreme dissaving of the public sector and the apparent weakness to the demand side to expand investment.

\section{Construction of the Growth Accounts}

Although empirical research on productivity growth has used a variety of methodologies, most of the analysis has evolved along two primary paths: growth accounting or direct econometric estimation. Both are based on the underlying concept of an aggregate production function. Growth accounting combines the production function with the assumption of competitive markets, leading to the usage of income shares to measure the contribution of factor inputs. This method focuses on identifying contributions of individual factor inputs and a residual, typically called total factor productivity (TFP). In contrast, the econometric approach avoids any assumption that markets are competitive, and focuses on exploring alternative functional forms for the production function. 
Most empirical studies have tended to emphasize what might be labeled the proximate causes of growth: measuring the quantity and quality of capital and labor inputs, and viewing the TFP residual as representing a combination of changes in efficiency and the production technology. More recently, some researchers have sought to go beyond proximate causes, so as to associate the fundamental sources of long-term differences in living standards with underlying differences in institutional and legal arrangements and geography. In these studies, TFP is perceived as the driving force behind growth. Accumulation of both physical capital and labor skills is taken to be largely endogenous -- and ultimately induced by changes in TFP. From this perspective, developing a theory of TFP is a central objective. ${ }^{1}$

\section{Basic Growth Accounting Framework.}

Building from the seminal work by Solow (1957), modern productivity analysis begins with the concept of an aggregate production function. As shown in equation (1), this relates output $(\mathrm{Q})$ to contributions of factor inputs, capital $(\mathrm{K})$ and labor $(\mathrm{L})$, as well as a Hicks-neutral shift in the production function (A):

$$
\text { (1) } Q_{t}=A_{t} F\left(K_{t}, L_{t}\right) \text {. }
$$

The next step is to combine the notion of a production function with the assumption of competitive markets in which factors are paid their marginal products. It is then straight-forward to derive a simple index number formulation relating growth in output to increases in factor inputs and a residual shift term, identified with TFP:

$$
d \ln Q=s_{k} d \ln (K)+s_{l} d \ln (L)+\Delta \ln T F P,
$$

where $s_{k}$ and $s_{1}$ are the shares of capital and labor income, respectively. ${ }^{2}$

As discussed more fully below, it is often difficult to obtain meaningful time series estimates of factor income shares. Thus, many studies adopt the more restricted

\footnotetext{
${ }^{1}$ Examples of this literature are provided by Klenow and Rodriguez-Clare (1997) and Easterly and Levine (2001).

2 The use of income share weights is critical, because this makes it possible to avoid imposing restrictions on the possible functional forms of the production function. In empirical applications, the factor shares are replaced by average between period shares in a Tornqvist discrete time approximation. Thus $\mathrm{s}_{\mathrm{k}}$ is replaced by $\left(\mathrm{s}_{\mathrm{kt}}+\mathrm{s}_{\mathrm{kt}-1}\right) / 2$. A summary of this literature is provided in Hulten (2001). OECD (2001) provides a detailed manual, elaborating on the major issues.
} 
Cobb-Douglas production function, which assumes the contribution of each factor to be constant:

$$
Q_{t}=A\left(K_{t}^{\alpha} L_{t}^{1-\alpha}\right)^{\gamma} \text {. }
$$

Again, A represents TFP and $\gamma$ measures the extent of returns to scale. In this restricted formulation, the $s_{k}$ and $s_{1}$ of equation (2) are replaced with constants. Many studies have also simply assumed returns to scale of unity. In the absence of an explicit allowance, returns to scale are subsumed within an overall residual of TFP. That is the approach used in this study.

It has become standard to adjust the factor inputs, particularly labor, to reflect changes in quality. Most of this research follows one of two common approaches. The first seeks to cross-classify the workforce by a number of differentiating characteristics, such as education, age, occupation and gender. Information on these characteristics is combined with data on wage rates, so to compute each subgroup's share of total compensation, $\mathrm{v}_{\mathrm{i}}$. An adjusted measure of the labor input is then computed as

$$
\text { (4) } \quad d \ln L^{*}=\sum_{i} v_{i} d \ln L_{i}
$$

However, this process is very data intensive. In addition, some analysts object that observed wage differentials may reflect factors other than productivity differences, such as gender or age discrimination.

The alternative is to use a simple index of educational attainment to adjust for skill differences. For example, an index of the form:

$$
L^{*}=e^{a s} L
$$

assumes that each year of schooling, s, raises the average worker's productivity by a constant percentage, a. This formulation has a ready parallel with the vast number of empirical studies that have measured the relationship between wages and years of schooling using "Mincer regressions". Such studies have been carried out for different time periods and for a large number of countries around the world, typically finding a return to each additional year of education in the range of 7 to 12 percent. $^{3}$

\footnotetext{
${ }^{3}$ References to many of these international studies are available in Psacharopoulos and Patrinos (2004). We will discuss several specific studies of India in a later section.
} 
Quality adjustments can also be made to the measure used for capital input -however, in most cases these are more properly identified as reflecting changes in the composition of the capital stock. Current approaches were developed from Jorgenson's neoclassical investment theory that clarified the distinction between the capital stock and capital services. Using his concept of user cost, the rental price of capital services is given by

$$
P_{k}^{s}=\left(i+\delta-\dot{P}_{k}\right) \bullet P_{k}
$$

where i represents the rate of return, and $\delta$ the rate of depreciation. $P_{k}$ and $\dot{P}_{k}$ are the price of a unit of capital, and its rate of change, respectively. This formulation makes it clear that the flow of capital services will vary with difference in the rate of capital asset depreciation. Assuming that the real rate of return is constant across asset classes, the capital service term can be used to compute capital income shares. In a fashion analogous to equation (4), these shares can then be used to aggregate capital of different service lives, thereby constructing an adjusted capital input measure. The growing importance of short-lived, high-tech capital has made the issue of compositional changes in the capital stock more important.

Unfortunately, few countries have sufficiently detailed information to make these types of compositional adjustments to their capital inputs measure - and India is no exception. The data constraints are particularly acute at the level of individual industries. Instead, an estimate of the capital stock is commonly used as the index of capital services. The essential difference between the two is that the capital stock aggregate is constructed using purchase prices as the relevant weights, while the capital services aggregate would be constructed using rental prices as weights.

Using this framework, we estimate a set of growth accounts over the period 196061 to 2004-05, for the total economy as well as for its three major sectors -- agriculture, industry and services - as well as for manufacturing. ${ }^{4}$ We have excluded residential housing from services and the total economy because income from housing is based

\footnotetext{
${ }^{4}$ We follow the grouping traditionally used by the UN and other international organizations. Indian statistical agencies use the same grouping, but refer to them as the primary, secondary and tertiary sectors. The agricultural sector includes forestry and fishing. Industry is comprised of mining, manufacturing, construction and utilities. The services sector covers the remainder of the economy.
} 
solely on imputations, and is all assigned to capital income. As described more fully below, the output and capital stock data are from the national accounts. These reflect the significant revisions associated with the adoption of the new 1999-00 base. Estimates of employment are based on results from the quinquennial household surveys.

\section{Data Sources}

The Indian statistical agencies face substantial challenges in preparing measures of output and employment at both the aggregate and sectoral levels. The difficulties arise primarily because a large portion of the nonagricultural workforce operates outside of standard reporting programs. Furthermore, India's national accounts are highly dependent on a series of quinquennial surveys for information on households and small enterprises. Therefore, annual estimates of output and employment (as well as estimates at higher frequencies), are largely based on either simple interpolations or on extrapolations of underlying source data. We have relied heavily on the comprehensive analysis of Sivasubramonian (2004) for the development of the requisite data at the level of the total economy. We have extended his analysis by incorporating recent revisions of the national accounts and by developing comparable growth accounts for major subsectors of the Indian economy (agriculture, industry, manufacturing, and services). We have also incorporated an alternative methodology to estimate the contribution of improvements in the educational attainment of the workforce.

In the remainder of this section, we discuss the data used to construct growth accounts for India. Output measures are considered first, followed by each of the factor inputs and, finally, measures of factor shares. Along the way, we summarize key data concerns and their implications.

Output. India has a reasonably good statistical system for measuring output of the agricultural sector and of non-agricultural enterprises that participate in government reporting programs, and are classified as part of the organized sector. ${ }^{5}$ For example, this

\footnotetext{
${ }^{5}$ A recent review of the Indian statistical system is provided in the 2001 Report of the National Statistical Commission, available at: http://mospi.nic.in/nscr/mp.htm. The commission identified some significant areas of deterioration in the agricultural and industry statistics, and it highlighted the dearth of information about service-producing industries.
} 
includes factories registered under the 1948 Factories Act, as well as large portions of mining, utilities, communications and finance. For these enterprises, it is possible to construct estimates of value added for national accounts, using either the production approach or the income approach. Furthermore, original source data are often available annually.

However, most workers are not included within the organized or formal sector of the economy. This point is clearly illustrated in Table 1, which provides data for 19992000. Its first three columns show the distribution of GDP by major industry, as well as the share of output in each industry produced in the organized versus the unorganized sectors. ${ }^{6}$ The final column shows the percent of employment that is unorganized in each sector. ${ }^{7}$ Within the nonagricultural economy, for example, fully 44 percent of the GDP was in the unorganized sector, and unorganized employment accounted for 88 percent of total employment.

For the unorganized sector, Indian measures of GDP are constructed using the labor input method. Thus, estimates of labor input at the industry level are combined with measures of value added per worker (VAPW) from a variety of enterprise surveys. In this context, it is important to note that labor input is defined in terms of the number of jobs, not the number of workers. The total labor input measure comes from the quinquennial household survey. Since the objective is to obtain an employment measure equivalent to the one that employers would report (inclusive of multiple job holding), the number of workers reporting a principal employment activity over the prior year is added to the number of workers reporting a subsidiary employment activity. Each worker could be recorded as having up to two jobs. No adjustment is made for full versus part-time work for either primary or secondary jobs. ${ }^{8}$ The measure of labor input in the organized

\footnotetext{
${ }^{6}$ The unorganized sector is a bit broader than the related concept of the informal sector. For further discussion of the classification issues in the Indian context see Saha, Kar,and Baskaran (2004) and Kolli and Hazra (2005).

${ }^{7}$ Note that the percent of employment in a particular industry that is unorganized may differ from the share of labor input to the unorganized sector. For example, labor inputs in the organized sector may include casual workers, who would be classified as "unorganized employment".

${ }^{8}$ The methods used to compute the labor input have varied significantly over time, further restricting the comparability of the estimates of industry value added. The 1950, 1970, and 1980 benchmarks used census estimates, whereas the 1993-94 and 1999-00 benchmarks used data from the quinquennial employment and unemployment surveys. The 1970 through 1990 censuses are known to have encountered severe problems
} 
sector is obtained from employer reports. Thus, labor input in the unorganized sector is simply a residual -- the difference between the two.

The techniques described above should generate reasonably good estimates of output in the benchmark years for which survey data are available. However, India has no consistent source of information about employment in the unorganized sector for the years between the quinquennial surveys. Annual information on value added per worker is equally limited, since the value-added data are also updated on an approximate 5-year cycle. Therefore, detailed calculations of output using the labor input method can only be undertaken for benchmark years. Estimates of value added for the years between benchmarks are obtained by interpolation. Estimates for years since the most recent benchmark are obtained by extrapolating the labor inputs, based on growth between the two most recent benchmarks.

Table 2 provides a stark illustration of the problems created by the lack of underlying annual survey data for the unorganized portions of the economy. The first column shows the sectoral composition of GDP, using the revised data. The next two columns show two estimates of 1993-94 GDP - one using the 1980-81 benchmark and the other from the 1993-94 benchmark revision. Column 4 shows the percentage difference between the two. The second panel provides parallel information for 19992000 GDP, comparing the estimate using the 1993-94 benchmark, with the revision from the 1999-00 benchmark. (We note that, prior to the introduction of the 1993-94 base, GDP data were rebased to the decennial census with the last benchmark being 1980. The Central Statistical Office (CSO) has now shifted to a procedure that ties benchmark revisions to the quinquennial household surveys.)

As shown in the fourth column of Table 2, revisions to 1993-94 GDP were substantial, raising the estimate of total GDP by fully 9 percent. In part, the sizable revisions that accompanied the shift to the 1993-94 base reflect the fact that it had been so many years since the introduction of the 1980-81 base. But it is important to point out that the revisions are quite small for those industries that are largely in the organized sector and for which annual sources of information are available. In contrast, the

in measuring the workforce (Visaria, 2002). Also the 1999-00 benchmark adjusted for multiple jobs at the level of individual industries, whereas the 1993-94 estimates relied on common ratios from aggregate data. Additional details are available in CSO (2004). 
necessity of relying on the labor input methodology and past rates of change to extrapolate output resulted in particularly large output revisions in the service-producing industries (15 percent, on average). Output for the category that includes business services was revised upwards by 103 percent. The lack of good output data for the service industry is a problem in all countries. It is of particular importance for India because of the prominent role that services are expected to play in the country's future growth.

The 1999-00 base revisions, shown in column 8 , were much smaller - both because fewer years had elapsed and because there had been fewer methodological changes. In addition, India adopted many elements of the 1993 Standard National Accounts, which contributed to some of the upward revisions of GDP. The revisions for agriculture and industry were minor, but output of the service-producing industries was increased by 4.5 percent, adding almost a percentage point to the annual growth rate. And once again, the revisions were quite large in some sub-sectors, such as the category including business services.

The problems with annual output estimates in non-benchmark years suggest that debates over the precise timing of changes in India's rate of GDP growth around episodes of economic reform should not be taken very seriously. Annual changes, based on extrapolations from the last benchmark, may be misleading. In contrast, the benchmark estimates themselves are constructed with considerable detail and a strong anchor in the quinquennial surveys. This provides a reasonable degree of confidence for focusing on those selected years to study India's economic performance.

In the past, The CSO has provided revised historical estimates of GDP and its components that are consistent with the latest benchmark. However, similar data have not yet been published following the introduction of the new 1999-00 base. In the absence of published data, we have assumed that the percentage revision of 1999-00 reflected a drift in the annual estimates and distributed this discrepancy back to 1993-94 in a linear fashion. We continue to measure output in 1993-94 prices. The output data of 1993-94 and earlier years are assumed to be unchanged. ${ }^{9}$

\footnotetext{
9 This procedure closely follows the description by the CSO for its revisions of the historical data after the 1993-94 revisions.
} 
Capital Stock Estimates. Estimates of the capital stock by industry are available back to 1950. However, these are dependent on the underlying measures of investment by industry, and there is little direct information on capital service lives. The CSO compiles two separate estimates of capital investment. First, aggregate investment by asset type is based largely on a commodity-flow method. Second, investment by industry is compiled from establishment surveys, which do not have asset detail. The two estimates have differed substantially in some years. We have used the industry-based estimates because we need estimates of the capital stock by broad industry groups.

The annual estimates of investment are subject to similar uncertainties between benchmark years as those discussed above with regarding output data. Again, the problems are most evident in the published revisions at the time a new base year is adopted. The 1993-94 benchmark revisions increased total investment of all industries by a relatively modest 9 percent. ${ }^{10}$ Somewhat surprisingly, the changes associated with the shift to the 1999-00 base are much more substantial -- despite the passage of just 5 years since the prior benchmark. Total industry fixed investment in 1999-00 has been increased by 33 percent, with revisions for agriculture, industry and services of 57, 17, and 46 percent respectively. ${ }^{11}$

The recent investment revisions are sufficiently large to have a major effect on estimates of growth in capital stocks since 1993-94. Since official capital stock revisions are not yet available, we have created new estimates for the major economic sectors, and for manufacturing, for the period of 1993-94 to 2004-05. As with output, we have phased in the investment revisions beginning in 1993-94. For the capital stocks, we created approximate measures using a fixed geometric rate of depreciation. These approximate measures were then recomputed for the period after 1993-94, using both the old and the revised estimates of investment. The percent adjustment for each year was applied to the corresponding official series to obtain our final revised capital stock series. For 2004-05,

\footnotetext{
${ }^{10}$ At the sector level, the percentage adjustments were -6 percent for agriculture, 18 percent for Industry, and 4 percent for services (Central Statistical Office, 1999, pp. 39-40).

${ }^{11}$ CSO (2006), table 30, p. 53. The revisions to the commodity-flow estimates were much smaller, but the methodology was changed to bring the industry estimates into line with those based on the commodity flow method.
} 
the last year of published data, our methodology implies that the revisions increased the overall capital stock by 15 percent, with even larger increases for agriculture and services.

Land Input Estimates. Our growth accounts include land as well as capital and labor as factor inputs to produce agriculture. An estimate of the volume of land used in agricultural production is available annually (Directorate of Economics and Statistics, 2005). However, there are no available estimates of current market value of the land that would enable us to construct measures of the annual flow of capital services. We use an estimate of total cropped land that adjusts for irrigated lands, sown more than once per year.

Employment. Difficulties also arise in the effort to construct reliable annual estimates of employment, and thus labor productivity. The censuses of 1971, 1981, and 1991 are believed to have produced solid estimates of the overall population, but they grossly underestimated the worker-population ratio (WPR) and thus the size of the total workforce. Visaria (2002) discusses these problems and suggests the need for corrections on the order of 26 (1971), 15 (1981) and 12 (1991) percent to the reported figures. ${ }^{12}$ In contrast, the quinquennial surveys appear to yield consistent estimates of WPRs, but to underestimate the total population. Thus, estimates of India's labor force are typically generated by combining the survey-based estimates of the WPR for four component groups (rural men, rural women, urban men and urban women) with estimates of the corresponding populations, obtained from interpolating the census data. As a result, reliable estimates of the total workforce are limited to the years covered by the six quinquennial household surveys that were conducted over the period of 1972-73 to 19992000. Annual estimates for the aggregate economy can only be obtained by interpolations and extrapolations of the results from those surveys. ${ }^{13}$

\footnotetext{
12 Provisional estimates of the WPRs are available for the 2001 census. The values appear to be much closer to the 1999-00 quinquennial survey than in past censuses.

${ }^{13}$ A recent evaluation of the potential usefulness of the smaller annual NSO surveys, which were undertaken in other years, is provided by Sundaram and Tendulkar (2005a). They concluded that the WPRs are not sufficiently comparable with those of the quinquennial surveys. Bhalla and Das (2006) reach a contrary conclusion.
} 
The NSSO surveys incorporate several distinct measures of the economic activities of the population. These are based on the prior year (usual status), the prior week (current weekly status) and each day of the reference week (daily status). They also distinguish between the principle activity status (plurality of time) and subsidiary status. Most researchers have relied on a count of persons with employment in usual status (either principle or subsidiary). However, unlike the national accounts their estimates are based on a count of persons, not a count of jobs. Visaria (2002) used estimates of worker participation rates from the quinquennial surveys and interpolated estimates of the populations of rural and urban males and females to produce estimates of the workforce. Sivasubramonian (2004) interpolated those estimates to obtain annual data for the aggregate economy.

We have updated the data of Visaria and Sivasubramonian using slightly different estimates of the WPRs by gender and sector from the NSSO surveys, and extended the estimates through 2004. We also used information from the surveys to allocate employment among the sectors: agriculture, industry (and manufacturing), and services. The calculations are shown in appendix table 1. The resulting estimates of employment apply to the seven years covered by surveys from 1973 to 2004 . We combined those observations with estimates from the 1961 Census, and interpolated the data to obtain annual measures of employment by sector for the period from 1960-61 to 2004-05. ${ }^{14}$

These employment surveys also provide information about the highest level of educational attainment for individuals in the workforce. These measures can be used to adjust the workforce for improvements in quality over time. Thus, for constructing the growth accounts, we computed average years of schooling for workers over age 15 in the three sectors of agriculture, industry, and services. We assumed a 7 percent return for each year of schooling in constructing an index of labor quality as in equation (5). ${ }^{15}$

\footnotetext{
${ }^{14}$ The differences with the aggregate estimates of Sivasubramonian are small. In addition, the $60^{\text {th }}$ round, conducted January - June, 2004, did not extend over a complete year; but when we compared the usual status WPRs for corresponding sub-rounds of the $55^{\text {th }}$ round, we found no evidence of seasonality. We opted to use the estimates from the $60^{\text {th }}$ round until those from the $61^{\text {st }}$ (a quinquennial round) become available.

${ }^{15}$ As discussed later, returns to schooling in India seem comparable to international experience, and the assumption of a 7 percent return is consistent with our estimates for other countries (Bosworth and Collins, 2003).
} 
Estimates of earnings are also available for four micro data sets that cover the $38^{\text {th }}, 50^{\text {th }}$, $55^{\text {th }}$, and $60^{\text {th }}$ rounds that enable us to compute estimates of the returns to education over the 1983-2004 period. The analysis of the gains in educational attainment and their relationship to earnings are discussed more fully in a later section.

Factor Incomes. The distribution of income payments between capital and labor is an important input into growth accounts because income shares, under conditions of competitive markets, can be used to measure the contributions of each factor without the need to rely on a specific functional form for the aggregate production function.

However, such estimates are problematic for India (and most developing countries) because of the dominant role of the self-employed in total employment. Their earnings, which are labeled as mixed income in the national accounts, reflect a combination of income from capital and their own labor. In industrial countries, where the income of the self-employed is a small proportion of the total, it is common to impute a wage equal to that of their employees or a return on capital equal to that of the corporate sector. However, in the case of India, mixed income accounted for 45 percent of NDP in 200203 , and 79 percent of the income of the unorganized sector, which is a slowly declining share of the total economy (CSO, 2005, p. xlv). The dominant role of mixed income raises strong doubts about the validity of the imputation technique for such a large income component. ${ }^{16}$

We have used fixed factor shares in our analysis. That implies a more restrictive range of production functions, but the analysis of industrial countries -- where information on factor income shares are available -- suggests little variation in share weights over time. We have also assumed constant returns to scale in all three sectors -any such gains are allocated to the TFP residual. For agriculture, our assumed shares are $0.5,0.25$, and 0.25 for labor, capital and land respectively. ${ }^{17}$ For industry and services,

\footnotetext{
${ }^{16}$ Sivasubramonian (2004) allocated mixed income between labor and capital on the basis of the distribution of income in the private organized sector. The result is a labor share that declines from 55-60 percent of GDP in the 1960s to 45-50 percent by the late 1990s.

${ }^{17}$ Evenson and others (1999, p. 40). The values are an average of their results for 1967, 1977, and 1987. They included a weight for fertilizer; but because our data are based on valued added, we scaled up the estimates for the other inputs. A similar procedure was used to compute agricultural TFP in Bhattarai and Narayanmoorthy (2003).
} 
we used a simple capital share of 0.4. For the aggregate economy, we combined the factor shares of individual sectors, weighted by their share of total nominal nonresidential GDP. The share of agriculture, for example, declines from 52 percent of the total in 1960-61 to 23 percent in 2004-05. We also conducted some sensitivity analysis using different values for the factor shares. However, in the case of India, choice of specific shares has little impact on the analysis because, in general, there have been relatively small differences in the growth rates for the labor and capital inputs. Thus, estimates of TFP are only marginally affected.

\section{India's Growth Accounts: Results and Discussion}

In this section, we present our updated growth accounts -- first for the total economy and then by major sector. The results reflect many of the now standard themes in the literature on India's economic development. However, some new findings emerge as well. Thus, drawing implications from our results, we build on the existing literature to discuss some of the key issues for India's growth experience and prospects for the future. The basic growth accounts are provided for the aggregate economy in table 3 and by sector in table 4 , and we refer to these data throughout the discussion.

\section{Aggregate Growth}

We begin by looking at growth performance over the relatively long periods 1960-80 versus 1980-2004 (top panel of table 3). This split reflects the widespread view that the performance of the Indian economy changed significantly around 1980. (However, as discussed above, there is an on-going debate about the role of economic reforms and the relative importance of changes undertaken during the 1980s versus those undertaken after the 1991 economic crisis.)

The acceleration of GDP growth after 1980 is clearly evident in the top panel of table 3 -- from an average of 3.4 percent per year during the period from 1960-80 to 5.8 percent during 1980-81 to 2004-05. It is noteworthy that nearly all of the output growth

during the first period is associated with increases in factor inputs. However, the post- 
1980 acceleration is concentrated in improvements in the efficiency of factor use, TFP. ${ }^{18}$ That the gains should be concentrated in TFP seems reasonable in light of the fact that the growth gains are typically attributed to shifts in the policy regime beginning around 1980 - that initiated an ongoing process of liberalization and opening up of the economy. The associated increases in reliance on markets and reductions in the role of government would be expected to result in improved economic efficiency.

However, there has been little or no net gain in the rate of job growth, and only a modest pickup in the rate of growth of both physical and human (education) capital per worker. As other authors have noted, this pattern is a striking contrast to that experienced by East Asian economies. Their periods of rapid growth have been characterized by strong employment gains, significant capital deepening, and rapid increases in educational attainment. ${ }^{19}$ We discuss India's experience with both human and physical capital accumulation in greater detail in a following section.

We can also examine shorter periods by focusing on the intervals between the quinquennial surveys. We argued above that data for these years are likely to be more reliable because the survey results are a primary input to the national accounts and provide the only direct measure of employment. As shown in table 3, growth in output per worker strengthened from just 1.8 percent per annum in 1973-83 to 2.9 percent in 1983-93 and 5.8 percent in 1993-99. These figures seem to imply a sustained improvement in the underlying trend. However, they do not enable us to pin down the precise timing of the growth acceleration. Growth did slow over the 1999-04 period, but this appears largely due to a severe agricultural drought in 2003-04. Moreover, preliminary data for 2005-06 suggest a strong 8.4 percent annual growth rate, and a threeyear average above 8 percent.

As discussed above, our measures of physical capital accumulation reflect the significant upward revisions to investment in the 1999-2000 benchmark. We have phased these in to our capital stock estimates beginning in 1993-94. The resulting contribution of increased capital per worker during 1993-99 of 2.4 percent per annum is

\footnotetext{
${ }^{18}$ Previous studies have also concluded that growth in factor inputs accounted for most of the growth in output during the "pre-reform" period. For example, see Dholokia (2002), who defines this earlier period as $1960-85$.

${ }^{19}$ Bosworth and Collins (2003)
} 
similar to levels observed during East Asia's rapid growth periods. However, India's capital deepening appears not to have kept pace with employment growth after 1999.

\section{Agriculture}

The growth accounts for the major sectors are shown in table 4. The first panel summarizes the growth performance of the agricultural sector. The contrast between the increase in labor productivity during 1960-80 (growth of just 0.1 percent per annum) versus 1980-2004 (1.8 percent per annum) highlights the role of the green revolution. In fact, the new technology began to be implemented in the early to mid-1970s. Our decomposition shows TFP growth jumping from -0.2 percent per year during 1960-73 to 0.9 percent per year during 1973-83, and to 1.2 percent during 1983-99. This estimated acceleration in TFP growth is consistent with a number of recent studies that focused on agriculture. ${ }^{20}$ It also is coincident with other changes that expanded the role of private decision-makers. There has been some concern that the rate of improvement in agriculture has begun to moderate, possibly suggesting lower returns to the government's $R \& D$ and extension service expenditures on the sector. However, our results do not suggest such a pattern -- except for the most recent five year period which includes the drought. There is still considerable margin, judged by the performance in comparator countries for improvements in agricultural yields.

One surprise is that agricultural employment continues to grow. The experience with similar stages of development in other countries has been that employment within agriculture tends to decline as underemployed workers are drawn out of agriculture into industry and services. In this context, India's experience is particularly notable because, as is well known, a relatively large share of India's employment remains in agriculture. However, the share of agriculture in value added is similar to that for other countries at similar income levels. ${ }^{21}$

\section{Industry}

\footnotetext{
${ }^{20}$ See, for example, Coelli and Rao (2003), Everson and others (1999), Foster and Rosenzweig (2004) and Janaiah and others (2005).

${ }^{21}$ For example, see Virmani (2005) for one recent discussion of this point.
} 
The second panel of table 4 shows that industrial output growth also quickened after 1980. However, the magnitude of this increase was less than for the economy as a whole. Employment growth rose by about 0.4 percentage points, to 3.5 percent per annum, while the contribution of capital per worker remained low, and the gains in educational attainment of the workforce have been modest. Although all of the improvement in labor productivity can be traced to higher growth in TFP, this also remains low by international standards. Further, the figures in Table 4 show TFP growth as slowing, not accelerating, during the post reform period. These results are disappointing in light of the attention that has been devoted to the on-going liberalization of the trade and regulatory regimes for goods production. However, they parallel the results of some other researchers, who also found somewhat disappointing performance of the industrial sector in recent decades. ${ }^{22}$

But a low rate of TFP growth in industry is not necessarily a surprise. First, it was a common feature of the early stages of growth in other Asian countries (Young, 1995). Certainly, the industrial base is likely to be inefficient initially, providing some room for productivity gains. But to the extent that developing country growth is a process of adopting the existing production technologies of more industrialized economies, longer-term gains in industrial sector TFP are likely to be minimal. The requisite capital and technology are purchased in global markets, and then combined with an advantage in low-cost labor to produce an output that is sold in competitive global markets. This is not a process that is likely to generate large productivity residuals - or large economic rents. Any TFP gains are more likely to be found in the production of goods for the domestic market, as inefficient producers decline in importance. At the aggregate level, gains in TFP will largely emerge from the shift of resources among the sectors.

In any case, there remains considerable scope for growth of India's industrial sector. In particular, India's employment share in industry remains surprisingly low given its development level. Raising living standards will require expansion of relatively labor-intensive activities, so as to productively employ the large pool of low-skilled

\footnotetext{
${ }^{22}$ Recent discussions include Wallack (2003) and Kohli (2006b).
} 
workers who are currently under-employed in agriculture. ${ }^{23}$ At its current stage of development, India's priority is to generate employment in industry. Less concern need be devoted to increases in sectoral TFP.

Because much of the discussion of India's economic growth has focused on manufacturing, we extracted it from the rest of the industrial sector and compiled a separate set of accounts. Our data include both the registered and unregistered portions of manufacturing. ${ }^{24}$ Together they account for roughly half of the industrial sector, but only about 15 percent of overall GDP. As shown in the third panel of table 4, the general pattern of growth for manufacturing is very similar to that for total industry. Like industry, manufacturing shows a sharp acceleration of growth after 1983. The investment boom of the mid-1990s and the subsequent collapse are also evident in the large change in the capital contribution before and after 1999-00.

Manufacturing experienced the same slowing of TFP growth after 1993 that was reported for industry as a whole, but the improvement in the last 5 years is more pronounced. The early and mid-1990s were marked by major reductions in industrial tariffs that intensified the competitive pressures on domestic manufacturing and mining. Thus, we would expect some initial reduction in TFP, but a steady pickup of growth as the old capital depreciates and new technologies are adopted by an increasing proportion of the industry. The cycle appears to have been amplified by a significant buildup of excess capacity in the mid 1990s, leading to a sharp downturn in both output and capital accumulation at the end of the decade. That excess capacity has been largely eliminated in recent years.

It is notable that employment growth in manufacturing has been consistently slower than for industry overall, giving rise to somewhat faster rates of growth of both labor productivity and TFP. However, the measure of TFP in manufacturing is sensitive to the precise factor share that is used to combine the inputs. This is the one case in which the growth rates of capital and labor differ by a significant amount in some periods.

\footnotetext{
${ }^{23}$ Many authors have made this point, including Banga (2005), Virmani (2005), and Krueger (2005). In this context, Foster and Rosenzweig (2004) highlight the role of increased non-agricultural activity in rural areas for raising rural incomes.

${ }^{24}$ The registered portion has increased from 58 percent of the total in 1980 to about 65 percent today.
} 
The general pattern of our results for the post-1993 period is comparable to the results reported in Goldar (2004). However his study used data from the Annual Survey of Manufacturing (ASI), and it related only to the registered portion of manufacturing. Goldar also found that TFP growth slowed somewhat after 1991, but the analysis could only cover the years up to 2001-02, the last year for which ASI data are available.

\section{Services}

The bottom panel of table 4 summarizes the growth performance of the services sector. As frequently noted, service-producing industries have been the primary source of India's growth surge, consistently outperforming industry/manufacturing. ${ }^{25}$ Indeed, since 1980, output growth has exceeded the pre-1980 growth rate by 2.7 percent per year -- and maintained an average annual growth of $7 \frac{1}{2}$ percent. Furthermore, employment growth in the sector has averaged 3.6 percent per year, roughly comparable to that for industry. However, increases in capital per worker have made an even smaller contribution to growth for services than for industry. The result is that gains in output per worker are dominated by high rates of improvement in TFP, averaging nearly three percent annually. We also note that this sector has registered the largest improvements in the educational attainment of its workforce.

Another perspective on the role of TFP in India's post-1980 growth is provided by figure 1, which displays annual TFP trends by sector and for the total economy. The dominance of the service-producing industries and the relatively weak performance of the goods producers are both very evident. The chart also shows that the growth of TFP in services has been remarkable consistent over the past quarter century and shows few signs of abating.

The source of such strong TFP growth in services, however, is puzzling. Information on employment is not available at a sufficient level of detail to compute productivity indexes; but greater detail is available for the output measures. Thus, table 5

\footnotetext{
${ }^{25}$ Banga (2005) provides a recent overview of the issues associated with India's rapid growth in services. He highlights explanations for and implications of the so-called "job-less growth" in India's service sector whereby increases in the share of GDP have not been associated with equivalent increases in the share of employment. Banga and Goldar (2004) argue that services are increasingly important as an input to Indian manufacturing. See also Gordon and Gupta (2004). Srinivasan (2005) focuses specifically on the development of India's IT sector and its implications for growth.
} 
reports growth in the component industries and their contribution to the growth of the total (defined to exclude housing). We have separated the sector into a modern component that includes communications, finance, business services, education and medical care, and a traditional sector of trade, transportation, public and personal services. Communications, finance and especially business services have received considerable attention as areas in which India has done well. The middle panel shows that these subsectors do indeed stand out, with high average rates of growth. Yet, business services account for just 5 percent of the overall sector's output, and the entire modern component accounted for less than half of the growth between 1980-81 and 2004-05. Instead, the acceleration of the sector's growth has been very broadly based, including trade, transportation, and community and personal services. But these are not industries in which we would anticipate rapid productivity growth. As stressed by Baumol (1967) services are normally an area of limited productivity growth. That characterization is changing with respect to portions of what we have called modern services because IT capital greatly altered the production process. On the other hand, although services are a major IT user in the United States, the adoption of the capital has not been accompanied by supernormal returns that might spillover into TFP. ${ }^{26}$ Education is another substantial sector in which we would not expect to observe significant productivity growth.

An alternative explanation is that increases in the price of services are being underestimated, leading to an overstatement of real growth. However, this hypothesis is difficult to verify. We can only note that while overall inflation has averaged about 7 percent since 1980, it has been remarkably similar for agriculture, industry and services. From an international perspective, the finding of large TFP gains in the service industries is atypical. Most countries, lacking measures of physical output, extrapolate the output of services with indexes of the inputs. ${ }^{27}$ Thus by construction, they eliminate the possibility of reported productivity gains. This does not appear to be a common practice in the Indian national accounts. While up-to-date information on the methods used to adjust for

\footnotetext{
${ }^{26}$ Triplett and Bosworth (2005).

${ }^{27}$ The most common methods are to use an index of employment to represent real growth, or equivalently to deflate the nominal values by change in average wage rates. In recent years, the U.S. and some other OECD countries have moved away from this input-based valuation by developing explicit price indexes for services. However, the method is still used for government and education.
} 
price inflation is limited, it appears that services output is often adjusted only for general (CPI) inflation (CSO, 1989). In the case of trade, margins are assumed to be constant in real value and change in line with total sales. Because so much of services lies outside the organized sector, the Indian statistical agencies have little or no direct information on the output of services. To a large extent, they are forced to rely on extrapolation of the base year values.

In summary, the growth of the service sector has been sustained and very broadly based. However, the extent that it is concentrated in TFP and not employment does give us pause. In addition, the lack of employment data at a more detailed level prevents us from exploring the source of the TFP gains in greater detail.

\section{Reallocation Effects}

A potentially important source of growth comes from the reallocation of resources from less productive to more productive activities. Traditionally, this has been associated with a shift of labor from agriculture, where there is initially substantial underemployment, to industry and then services. Output per worker in industry and services is 4 to 5 times that in agriculture. Thus, employment shifts from agriculture to either of these sectors should contribute to substantial gains in productivity and average incomes. However, as already discussed, the decline in agriculture as a share of Indian value added has been associated with relatively little reallocation of employment.

Table 6 provides an estimate of the contribution of factor reallocation to India's growth. The first column shows growth in total output per worker for various periods. The second column shows the combined contribution of growth in each of the three sectors, weighted by the sectoral shares. The data for total and sector growth are taken directly from tables 3 and 4 . Thus, the reallocation effect is simply the difference between the first and second columns, as shown in column 3. Post-1980, our calculations show that this reallocation contributed roughly one percent per year to output growth. 
Our findings also suggest that this component has become increasingly important in recent years. $^{28}$

\section{The Role of Capital Accumulation: Additional Perspectives}

In recent years, controversy has surrounded the roles of physical capital and education (human capital) in the growth process. Young (1995) has shown the dominance of physical capital accumulation in the growth of the East Asian economies. On the other hand, Klenow and Rodriguez-Clare (1997) argue that physical capital accumulation is largely induced by increases in TFP, a phenomenon that leads to an overstatement of the contribution of physical capital as an exogenous source of growth. Easterly and Levine (2001) argue that only a small percentage of the variation in growth across countries could be attributed to capital accumulation. Baier and others (2006) argue the opposite. Our own reading is that both capital accumulation and gains in TFP are important components of the growth process (Bosworth and Collins, 2003), although we agree that the precise magnitude of the role varies across countries. Capital accumulation is a necessary part of the process -- regardless of whether it is an exogenous or induced factor. Furthermore, the investment underlying that capital accumulation must be financed through national or foreign saving.

The role of education has been equally controversial. Many studies, including our own, have relied on the strong microeconomic association between education and earning to adjust the workforce for improvements in educational attainment. ${ }^{29}$ Again, rapid gains in educational attainment have been a particular feature of many of the fast-growing East Asian economies. Easterly (2001) and Pritchett (2001) question the relationship between education and growth at the aggregate level.

\footnotetext{
${ }^{28}$ See Bosworth (2005) for a similar calculation applied to Thailand. Using a different methodology, Wallock (2003) also concludes that much of India's post 1980s growth is attributable to resource movements.

${ }^{29}$ See Bosworth and Collins (2003) for a discussion of the differing perspectives.
} 
The growth accounts presented above imply that both human and physical capital have made relatively modest contributions to India's growth performance by international standards. We examine each of these areas in more detail below. Our examination of human capital first reviews the evolution of educational attainment. Using individual level data for selected years from 1983 to 2004, we then present new estimates of the extent to which Indian labor markets reward workers for various levels of additional schooling. This issue is of particular relevance, because increases in educational attainment have evolved somewhat differently in India than for other rapidly growing Asian economies - beginning with the push at tertiary levels, educating large numbers of engineers and scientists, and only since 1986 emphasizing primary education more broadly. Finally, the section turns to a discussion of investment and saving in India. While India's national saving rate has been rising and compares favorably to that for low income countries, it remains below that for high growth Asian economies. Is saving likely to act as a constraint for India's growth? We use the accounting identity linking investment to saving to frame our discussion, and explore the evolution over time as well as across sectors. Once again, a variety of issues arise, regarding the data available for measurement of both saving and investment.

\section{The Contribution of Education}

India is often cited as having a large cadre of well-educated university graduates. However, overall levels of educational attainment are low compared to the East Asian countries at similar stages of development. ${ }^{30}$ An international comparison suggest that India has only now reached an average level of schooling comparable to that achieved in other Asian countries a quarter century earlier (table 7). Today, most East Asian countries, including China, maintain a substantial lead over India in terms of the averageyears-of-schooling. Using results from the household surveys, table 8 provides a more detailed perspective on the changes in educational attainment of workers since 1960. The first row shows that there has been a substantial reduction in the proportion of the workforce that is illiterate -- from 72 per cent in the 1961 census. But illiteracy remains

\footnotetext{
${ }^{30}$ Primary education did not become a national policy priority in India until 1986. The national Program of Universal Elementary Education was launched in 2001. (For example, see Wu, Kaul and Sankar (2005).
} 
high, at about 40 percent currently. Those who have completed secondary schooling account for about 14 percent of workers, while an additional 6 percent have a university degree. Surprisingly, if we limit the analysis to those aged 24-34 in 2004, the proportion with a secondary education or better only rises from 20 to 25 percent.

Education appears to earn a very good return in India, comparable to that of other strongly growing countries. We obtained the micro household data files of the $38^{\text {th }}$ (1983), $50^{\text {th }}$ (1993-94), $55^{\text {th }}(1999-00)$, and the $60^{\text {th }}(2004)$ rounds of the NSSO employment surveys. These are large surveys that provide estimates of the earnings of workers (regular and laborers) as well as their educational attainment -- measured, as in table 8, by the highest level completed. Regression estimates of the relationship between schooling and earning in each of the four surveys are shown in table $9 .{ }^{31}$ A pattern of strongly increasing earnings at each level of education is clearly evident. Except for some evidence of a decline in the return to a secondary education in the 2004 survey, the magnitudes of the estimated returns are highly stable across time.

We also explored an alternative formulation that replaced the categorical variables with a single index of years of schooling. ${ }^{32}$ (In this formulation, we added two years for those with a technical degree or certificate.) The estimation results imply an average rate of return that varies between 9.1 and 9.8 percent per year of schooling. For comparison, Psacharapoulus and Patrinos (2004) report an average return to additional schooling of about 10 percent both overall and for the sub-group of Asian economies. However, the returns to schooling in India are not quite as uniform as the log-linear formulation would imply. Table 10 shows the annual marginal returns for different levels of schooling implied by the regression results in table 9. Interestingly, the incremental returns to primary education are significantly lower than the average returns, and there is a large jump in the return associated with completing the secondary level of schooling (10 or 12 years). The additional return to a university degree was low in the 1980s, but it has been rising rapidly in the latest surveys. This is consistent with the view that India may have

\footnotetext{
${ }^{31}$ Our results for the 1983 and 1993-94 surveys are very similar to those of Duraisamy (2000), who used the same two data sets. Dutta (2004) found somewhat lower returns. However, her analysis included other determinants that are likely to be correlated with educational attainment.

${ }^{32}$ Most states have adopted a system of five years for primary, three for middle school, and two each for secondary and higher secondary. We have treated a university degree a equivalent to three years,and added an additional two years of schooling for those with a technical degree.
} 
over-invested in higher education in earlier decades for fields such as engineering, leading to the large diaspora of Indian engineers abroad. The rising return in recent years is reflective of the changed economic situation, and the potential emergence of a scarcity of highly-skilled workers.

These deviations in the return to schooling from a simple log-linear relationship contrast sharply with results for some other countries. ${ }^{33}$ Psacharapoulus and Patrinos (2004) report a general global pattern in which the returns are highest for elementary education and decline slightly for higher levels of educational attainment. Those findings have been used to argue for shifting public resources toward primary education and reduction of illiteracy. However, our results suggest benefits from greater effort to ensure that more students complete the secondary education level. In part, the pattern of returns we find can be traced to strong gender effects in the relationship between education and earnings. Women are particularly disadvantaged at low levels of education, but do gain correspondingly more from secondary and tertiary education. In our analysis, the jump in incremental returns upon completion of the secondary level is particularly pronounced for women.

The finding of a relatively low return to an elementary education is consistent with several recent articles that have been critical of the quality of the primary education system. $^{34}$ There has also been a large move from public to private schools; but that may compound the problems as the poor are increasingly isolated and left behind in the process. Kapur and Mehta (2004) offer an even more critical perspective on the system of higher education. They argue that a crisis of governance in the public institutions is forcing students into private universities and to enroll abroad. Such criticisms of India's education system stand in sharp contrast to a generally favorable foreign perspective on the Indian education system, perhaps because so many of the highly-educated have emigrated. They also raise challenges for a growth strategy that aims to build on economic activities that have a large skill component.

\footnotetext{
33 The analysis of similar surveys for Thailand found no significant deviation from a log linear return of 10 percent (Bosworth, 2005). Also, our own analysis of U.S. data suggests a log-linear relationship is an adequate summary of the relationship between earnings and education.

${ }^{34}$ Kochar (2002), and Kremer and others (2005). Psacharapoulus and Patrinos (2004) also report a surprisingly low return to primary education of 3 percent,
} 


\section{Saving and Investment}

The small contribution of capital per worker to economic growth that is evident in the growth accounts highlights important issues about the adequacy of Indian saving and capital accumulation for sustaining high growth in the future. However, several studies have pointed to strongly rising rates of saving and investment shown in the national accounts to argue that capital accumulation should not be a major constraint on future growth. ${ }^{35}$ At the same time, the magnitude of recent revisions to the national accounts also raises questions about the reliability of the saving and investment data and the extent to which they reflect the underlying reality (Shetty, 2006). In this section, we address these issues, beginning once again with a discussion of the data available for analysis.

In the Indian national accounts, total saving is the sum of three separatelycompiled components: (1) public sector saving, (2) corporate saving and (3) household (including non-corporate enterprises) saving.

$$
\text { (7) } S_{T}=S_{p u b}+S_{c}+S_{h} \text {. }
$$

The CSO can construct reasonably good estimates of public sector saving from budget records. Its measure of corporate saving is compiled from a sample of major corporations' income and balance sheets, maintained by the Reserve Bank of India. Household saving is further divided into two independently-estimated components: physical saving, and net financial saving. Saving in physical assets is simply set equal to investment of the household sector, which is itself a residual estimate, as explained below. The estimate of household financial saving is constructed from flow-of-funds measures of the net addition to total financial assets less the accumulation of the public and corporate sectors.

The overall national saving rate and its three components are shown as percentages of GDP for the period 1970-2004 in figure 2a. The overall saving rate has risen strongly, especially since the mid 1980s. Further, this increase is dominated by major gains in household saving. Public sector saving actually turned negative in the late

\footnotetext{
${ }^{35}$ See, for example, Mühleisen (1997) and Rodrik and Subramanian (2004b).
} 
1990s, but with some recent improvement. Corporate saving (retained earnings) grew substantially up to 1995 , but has since remained in the range of 4-5 percent of GDP.

Thus, the expansion of saving is concentrated in the household sector. Total household saving has increased from a modest 10 percent of GDP in the early 1970s to 25 percent today. Furthermore, in the 1970s, over two-thirds of household saving was in physical saving, implying that it was dominated by housing and own-account construction, much of which never passed through financial institutions. (An unknown portion represents the investment of unincorporated business that are included as part of the household sector.) The most impressive growth has been in the category of financial saving, which increased from about 4 percent of GDP in the early 1970s to 12 percent in recent years and now represents half of household saving. These funds are available to finance investment in other sectors.

On the investment side, the CSO constructs two direct measures. The first is an estimate of total investment derived using the commodity flow method. Under that method, the total supply of capital goods is estimated from domestic production and imports and then apportioned among intermediate inputs and the various components of final demand. Of necessity, many of the demand components and some of the elements of domestic production must be estimated using various fixed ratios. Investments of the public sector and of private corporations are obtained from the same sources used to estimate their saving. Household investment (physical saving) is derived in turn by subtracting public and corporate investment from the total.

A second direct estimate of capital accumulation is built up from individual industries, based largely on the expenditure approach. Measures of both fixed investment and inventory accumulation are constructed from a variety of sources, including surveys, public budget documents, and annual reports of public and private enterprises. Given the importance of the unorganized sector, this latter set of estimates is particularly tenuous -but they provide the only information on the distribution of investment at the industry level.

Finally, by combining the estimate of national saving with the current account balance of the balance of payments (CA), the CSO can derive still a third indirect measure of total investment: 
(8) $I_{T}=S_{T}-C A$.

Thus, the CSO actually has three alternative measures of aggregate capital accumulation that are largely independent of one another. Prior to the last revision (1999-00 base), all three measures were published with their associated discrepancies. Since the CSO views the valuation from the saving side as the most reliable, this is the one that is emphasized in the aggregate table. The various measures of investment and saving are shown for the period of 1960 to 2004 in appendix table 2.

With the introduction of the 1999-00 base, the CSO made several changes to its calculation and presentation of the alternative measures of capital formation. First, the definition of capital accumulation has been changed to include an estimate of net purchases of valuables. ${ }^{36}$ By 2004-05, these purchases represented 1.4 percent of GNI. However, no comparable change was made to include valuables on the saving side. Since the saving-side measure of capital accumulation has been the larger in recent years, this definitional change had the effect of sharply reducing the magnitude of the reported discrepancy between the saving and the commodity-flow measures of capital accumulation. However, we have retained the old treatment and excluded valuables from our measure of productive capital.

Second, the CSO elected to eliminate the second discrepancy between the commodity-flow and industry-based estimates by distributing the discrepancy across the industry groups in proportion to their estimated levels of investment. The result was a dramatic upward adjustment of the industry-based investment of 30 percent in 1999-00. ${ }^{37}$ A previous pattern of a declining rate of investment - particularly within industry-- was converted into a strongly rising trend. We integrated the new 1999-00 and subsequent estimates of both saving and investment into the historical data by phasing the changes in between 1993-94 and 1999-00, the same procedure that was used to link in the revisions to the other GDP data.

\footnotetext{
${ }^{36}$ The accounts also adopted the suggestion of the 1993 SNA to include purchases of computer software, but the accounts do not include the development of own-account software and databases as investment.

${ }^{37}$ The revision to the commodity-flow estimate was a more modest 12 percent.
} 
The composition of investment by institutional sector is shown in figure $2 \mathrm{~b}$. It is readily evident that the household sector has become an important source of finance for both private corporations and the public sector. The investment of both sectors is much larger than their own saving. The growth of investment, however, is concentrated in households and corporations, while public sector investment has been a consistently declining share of GDP. The increase in the household sector is largely due to the growing importance of private noncorporate enterprises. While there was a substantial upward revaluation of real estate investment (concentrated in the household sector) in the 1999-00 revisions, the growth in household investment is substantially larger. ${ }^{38}$

Additional information on the role of the public sector is given in table 11. First, the historically low rate of public saving has primarily been due to the large dissaving in the administrative budget. The shortfall of revenues relative to current outlays first emerged in the mid-1980s and then grew steadily over the years. After peaking in 200102 at 6.6 percent of GNI, the administrative budget deficit has been cut in half in recent years. Saving within public enterprises has increased over the past decade, so that total public sector saving turned positive in 2003-04.

Investment of public enterprises did rise significantly in the $1980 \mathrm{~s}$-- a point made by those who point to demand stimulus as a cause of the acceleration of growth in the 1980s. ${ }^{39}$ However, enterprise investment was steadily cut back after the surge of the 1980s. Investment in the administrative budget has remained very low in recent years -between one and two percent of GNI. The low investment within the administrative budget reflects a longstanding lack of attention to infrastructure needs, particularly road building. Some other types of infrastructure investment are captured in the industry data for public utilities, transportation and communications, shown as an addendum to table 11. Again, this type of investment has also remained low as a share of GNI.

Some of the increase in the rate of gross investment that has taken place over the last quarter century has been offset by a rise in capital consumption allowances as a share of GDP. During the latest 5-year period (2000-04), net investment has averaged 17

\footnotetext{
${ }^{38}$ As discussed in the section on growth accounts, the national accounts do not currently separate investment of the business services industry from that of real estate investment. That is unfortunate given the interest in the rapidly expanding business services industry.

${ }^{39}$ See Srinivasan (2003b) and Buiter and Patel (1992).
} 
percent of GDP (appendix table 2). The aggregate capital-output ratio has also been a stable 2.5 times GDP. These figures suggest that the current rate of capital formation is sufficient to support a growth rate of about 7 percent per annum.

Is saving constraining India's growth? To the contrary, we think the evidence suggests a higher potential growth rate should be quite feasible. First, the private saving rate appears to be rising over time. ${ }^{40}$ Second, India should be able to support a significantly higher rate of foreign saving (current account deficit), particularly if this were financed by higher rates of FDI. Third, there continues to be substantial room for improving the saving performance of the public sector.

As an additional reason for believing that current rates of saving are adequate to support future growth, we note that we can find little evidence of heightened competition for domestic capital. We constructed a lending rate by averaging the rates of four major lending institutions, as reported by the Reserve Bank of India (RBI). A real interest rate was computed on an annual basis using the ex-post realized rate of increase in the Wholesale Price Index. These data are summarized in table 12. While the real rate shows considerable fluctuation, there is little evidence of a secular increase. Although the rate rose in the late 1990s, this appears to have been a transitory response to a sharp decline in the inflation rate. Furthermore, a real interest rate in the range of 5-7 percent is not particularly high for a developing country.

Overall, this evidence suggests to us that the low contribution of capital accumulation to growth has largely been a product of the incentives to undertake investment, rather than a saving constraint. Hallward-Dreimeir (2005) provides a recent overview of the literature on business climate and its implications for investment and private sector activity. Referring to the World Bank's survey based indicators - "Doing Business" - she finds that India ranks in the bottom 25 percent of countries. The survey highlights firms' concerns, including poor access to electricity, and stringent labor regulations. The public sector, in particular, has not responded to obvious signs of insufficient infrastructure capital.

\footnotetext{
${ }^{40}$ Several international studies of saving in developing countries conclude that there is a strong positive association with the level of income. For a discussion see Mühleisen (1997), and Loayza and others (2000). Also, India's demographic trends support the notion of continued increases in private saving (Higgins and Williamson, 1997).
} 


\section{Implications for the Future}

India is still a very poor economy, and increasing overall living standards is clearly the major priority. To achieve this, it is necessary both to raise labor productivity, and to speed up the pace of job creation for those currently underemployed in rural agriculture. Our analysis in prior sections points to three implications for achieving this critical objective.

First is a need to broaden the base of the economic expansion beyond the modern service sector, which, by itself, can not provide the requisite number of job opportunities. This implies a much more rapid expansion of the manufacturing sector, which will require strengthening India's infrastructure, raising private sector investment and adopting a more aggressive approach to expanding India's export markets. A second implication of our work is good news -- India has strong prospects for increasing the saving necessary to finance the additional capital accumulation. The third focuses on accelerating the pace of improvements in the educational attainment of the population: This requires a greater emphasis on increasing primary and secondary schooling, as well as expanding its already substantial pool of highly educated labor. Finally, the lack of reliable annual statistics on employment is a major limitation on efforts to evaluate current economic performance. Thus, we believe that India would benefit greatly from undertaking an ongoing household survey that would provide annual time-consistent measures of labor-market performance. While we are certainly not the first to advocate these actions, we believe our analysis sheds additional light on the reasons for their importance.

Over the past decade, India's economic growth has been concentrated in the service sector. On the one hand, there are many positive dimensions of this development. India's rapid in-roads into global markets for products such as business services have increased domestic exposure to the world marketplace in areas with considerable room for expansion. As we have seen, the services growth is not limited to a few selected IT related activities, but appears to be considerably broader than often recognized. And 
recent studies have found that growth in services has generated increased demand for industrial products as well. ${ }^{41}$

While India's very rapid recent growth in services is well known, some other unusual dimensions of its growth pattern have received less attention. Kochhar and others (2006) compares India's development pattern to that for a large cross section of economies, controlling for both per capita income levels and country size. They find that, in 1981, India was an outlier in terms of the relatively low share of services in both GDP and employment. While the share devoted to manufacturing did not stand out at that time, they find that Indian production was concentrated in relatively skill-intensive industries. Between the early 1980s and 2002, the share of agriculture in India's GDP declined, while the share of services increased. Currently, the Indian economy does stand out for its relatively low manufactures share of GDP, and the high proportion of employment remaining in agriculture. The paper also notes that both manufactures and services are relatively concentrated in skill-intensive output. Virmani (2005) points out that the manufactures share of GDP was just 15.8 percent in 2003, well below comparator countries in East Asia. For instance, manufactures shares ranged from 21 percent in Vietnam to 39 percent in China. ${ }^{42}$

This development pattern is not one that offers expanding job opportunities for a labor force that is dominated by relatively low-skilled workers. Only a rapidlyexpanding manufacturing sector, producing labor-intensive products for both global markets and the domestic economy, offers the prospect of creating a large number jobs aligned with the skills of the majority of the Indian workforce.

How could India encourage the development of a private manufacturing sector, as a companion to the vibrant services industries? In recent years, considerable research has sought to identify the determinants of private sector growth, with much of the analysis emphasizing the importance of the investment climate faced by entrepreneurs. An attractive environment for doing business is now typically seen as having a variety of dimensions, ranging from access to infrastructure and financial services, to factors such as the security of property rights and a simple and transparent regulatory system. The

\footnotetext{
${ }^{41}$ See Banga and Goldar (2004)

${ }^{42}$ Kochhar and others (2006) also examine the patters of development across India states.
} 
World Bank's Investment Climate and Doing Business Surveys are intended to strengthen available measures of these and other aspects of the investment climate by including a number of objective questions as well as some more subjective ones. Both cover a large number of countries, including India. Many of these indicators have been shown to have a strong correlation with growth in cross-country studies, and with labor productivity in micro-economic studies of firm behavior. ${ }^{43}$

How does India fare in this evaluation of its business climate? There is both good news and areas for concern. The Business Competitiveness Index for 2004 ranks India $37^{\text {th }}$ out of 101 countries. This relatively favorable assessment largely reflects the pool of highly skilled scientists, engineers and strong management programs. The main concerns include regulatory issues and inadequate infrastructure. ${ }^{44}$ Thus, India ranks a poor $116^{\text {th }}$ out of 155 countries in the 2005 Doing Business indicators, which focus only on 10 regulatory areas. It does particularly poorly in terms of enforcing contracts $\left(138^{\text {th }}\right)$, trading across boarders $\left(130^{\text {th }}\right)$ dealing with licenses $\left(124^{\text {th }}\right)$ and employing workers $\left(116^{\text {th }}\right)$. However, India ranks $84^{\text {th }}$ in terms of getting credit and a strong $29^{\text {th }}$ for protecting investors. $^{45}$

Results from India's Investment Survey highlight concerns about infrastructure especially electricity. ${ }^{46}$ Respondents noted very high delays in obtaining electrical connections and large value lost to electric outages. The World Bank report concludes that India's power supply difficulties arise largely from problems with transmission and distribution (T\&D). In 2003, the average Indian firm experienced power outages nearly every other day - more that three times the frequency endured by businesses in Brazil, and more than seven times that endured in China. The study also reports that output losses due to outages in India were more than four times those in either China or Brazil.

\footnotetext{
43 For example, see Hallward-Driemeier (2006). Dollar, Iarossi and Mengistae (2002) find that differences in investment climate across Indian states explain a substantial share of the differences in laborproductivity, using a sample of 1000 manufacturing firms.

44 See Hallward-Driemeier (2006).

${ }^{45}$ See http://www.doingbusiness.org/

${ }^{46}$ Summary information for India's results in the Investment Climate Survey are available at: http://rru.worldbank.org/EnterpriseSurveys/ExploreEconomies/Default.aspx?economyid=89
} 
Furthermore, average power tariffs for industrial use in India are relatively high - around \$0.08 per kwh compared with \$0.05 elsewhere in Southesast Asia. ${ }^{47}$

Virmani (2005) notes that there are two fundamental problems that must be addressed. First, policy and regulatory risks are still too high, despite the passage of the Electricity Act of 2003, discouraging the entry of private producers. Second, the issue of T\&D losses (in reality, utter theft) has not been seriously addressed. Officially reported T\&D losses at the all-India level were 32.5 percent of total availability in 2003-4. Others have suggested that independent audits would place these losses closer to 50 percent of available capacity. Private entry into distribution cannot be sustained unless organized theft is eliminated and T\&D losses brought down to levels considered normal across the World (i.e. around 8\%).

Major concerns have also been raised about logistical difficulties in India. In particular, road networks are relatively poor, limiting internal transport, especially in some poorer regions. Detailing both infrastructure problems and operational weaknesses, a 2002 World Bank study concluded that "poor transport has become a major drag on economic growth."48 The study notes that China had roughly five times the kilometers of four to six-lane expressways. Most Indian national highways are only one or two lanes, and heavy congestion on both national and state roads implies that trucks and buses can travel at, on average, just half the expected speed. The 2004 report notes that India's major economic areas are not linked by an inter-state highway system. In contrast, China is enjoying the benefits of having undertaken an extensive investment in its highway system over the past decade. ${ }^{49}$ We also note the dramatic effect that building a system of interstate highways had for the United States, as suggestive of the benefits of such a program for India. Although the government has announced a major program to upgrade and extend the highway system, implementation has been constrained by a lack of funding.

On the more positive front, over 70 percent of respondents in the Investment Survey expressed confidence in India's judiciary system, compared with less than 60

\footnotetext{
${ }^{47}$ World Bank (2004). See esp. pp. 35-36.

${ }^{48}$ World Bank (2002) p. 7.

${ }^{49}$ World Bank (2004), p. 36.
} 
percent overall and just 48 percent in South Asia. Furthermore, India has achieved major gains expanding access to high quality communications services, primarily by relying on a rapid expansion of the private wireless component.

The discussion above stresses areas in which additional investment is needed to make India an attractive business location. Our analysis suggests that the saving, required to finance the investment, does not appear to pose an additional constraint. In this dimension, we believe that India's prospects are quite favorable. It is true that the overall saving rate has not been as impressive as that of the high-growth East Asian economics. However, India's private saving rate was comparable to the developing country average in the mid-1960s, and has grown more rapidly. ${ }^{50}$ As incomes increase, experiences elsewhere suggest that India's private saving would be expected to increase somewhat further.

Equally important, India has considerable scope for raising foreign saving through increased FDI. A number of studies have documented that there are strong positive effects of increased FDI flows for domestic investment. However, to date India has received little of the very substantial global FDI flows to developing countries. Virmani (2005) notes that during 1980-2003 FDI flows averaged only 0.3\% of India's GDP, putting India in the $7^{\text {th }}$ percentile of his sample of 82 medium large countries. Despite some recent liberalization, India's ranking remains near the bottom of such indicators. Estimates of the stock of FDI assets by country constructed by Philip Lane and Gian Maria Milesi-Ferretti show that as a share of GD India's FDI stock is less than one fifth that for China.. ${ }^{51}$

Concerns about the adequacy of national saving are centered on the behavior of the public sector. As discussed in a prior section, the public saving rate has fallen dramatically over the past twenty years. In part, this reflects a deteriorating situation within the public enterprises, requiring substantial subsidies and other transfers from the central administrative budget. In addition, central administrative budget deficits have become endemic.

\footnotetext{
${ }^{50}$ For example, see Loayza and Shankar (2000).

${ }^{51}$ Lane and Milesi-Ferretti (2006). Their data are available at http://www.ssc.wisc.edu/ cengel/CAConference/WP_External\%20Wealth_final.pdf
} 
Finally, the assessment of India's economic performance is made difficult by the lack of statistical coverage of large portions of the economy. In particular, there is no consistent information on employment between the quinquennial surveys. At a minimum India need an annual survey for the intervening years. The quality of the quinquennial surveys appears to be high, but the development of the sample frame for each survey is a major undertaking. In addition, by constructing a large portion of the sample frame as a new undertaking for each survey, the results have suffered from a lack of consistency over time. We believe that the maintenance and continue use of the sample frame from the quinquennial survey over the following five years would provide a relatively low cost means of obtaining time-consistent employment data.

\section{Concluding Remarks}

In this paper, we have revisited some of the key issues regarding India's economic growth performance and prospects. Our work updates previous studies, and presents results based on analysis of new data. Our analysis focuses on the periods de-lineated by the survey benchmark years: 1960, 1973, 1983, 1993, 1999 and 2004 due to concerns about India's annual output data. We have argued that researchers should have a reasonable degree of confidence in the GDP estimates for benchmark years. However, for non-benchmark years, annual output data are based on interpolation and extrapolation of the labor input data required to construct output measures for India's large unorganized sector. These estimates have been subject to substantial revisions. We conclude that the lack of reliable annual series make it impossible to pin down the precise timing of India's growth acceleration. Although it does seem clear that growth accelerated after 1983, the precise triggering events and the sustainability of this growth remain topics of on-going debate.

India's output growth has doubled from just 3.3 percent per year during our initial period of 1960-73, to over 6 percent per year during the past decade. In the initial period, we find that growth can be fully attributed to increases in factor inputs - with nearly twothirds accounted for by increased employment, and a third by increases in capital per 
worker. Growth accelerated to 4.2 percent per year during the second sub-period, 197383. Just over half of the gains are associated with TFP, and the remainder with employment. The acceleration appears related to the green revolution, with gains accruing to both increases in agricultural TFP and sectoral reallocation. Labor productivity declined in both services and industry. There was a further, modest, acceleration of output growth, to 5 percent per year during 1983-93. This increase can all be attributed to increased TFP, concentrated in services and industry (especially manufacturing). However, analysts remain divided on the reasons for the rise in growth during this period, with the many possible explanations including (unsustainable) fiscal expansion and response to initial policy reforms.

Output growth surged to 7 per cent per year during 1993-99. Given the somewhat puzzling decline in employment, there is a particularly large jump in labor productivity concentrated in services but evident in all sectors. It is associated with rises in both TFP and capital deepening. Output moderated somewhat during the most recent period (19992004) with growth slowing in all sectors, in part due to the severe drought. Contributions from TFP and capital deepening slowed in both services and industry. Notably, investment failed to keep up with the more rapid employment growth. However, we note that the two latter periods are quite short. Growth accounting is most appropriate for relatively long time periods of a decade or more, in which output performance is not dominated by cyclical shocks.

Considerable attention has been focused on the role of services - especially hightech services - as the source of India's growth. Our growth accounts attribute 1.4 percentage points of the 3.8 percent per annum GDP growth during 1980-2004 to growth in total services output (versus 0.7 percentage points each to agriculture and industry and 1 percent to reallocation, respectively). However, the very strong gains in service sector TFP are quite puzzling. One might expect such rapid productivity growth in sub-sectors such as finance and business services, but these sectors remain small - just 17 percent of total services output in 2004. In fact, the output growth is quite widely dispersed across service sub-sectors. But rapid productivity growth seems unlikely in the biggest, which are trade, transportation and community services. Though difficult to verify, we hypothesize that output growth in services has been overstated due to an underestimate of 
services price inflation, particularly in the more traditional sectors. We have more confidence in the estimates of the growth in employment.

The accounting decomposition finds that the growth contribution from increases in education has been quite modest. While India can boast a relatively large share of highly educated workers for its income level, average years of schooling and literacy rates among its population remain low, and the effort to achieve universal primary education is quite recent. Not only does India have a long way to go to catch up with competitors such as China, the rapid increase in school enrollments appears to have exacerbated concerns about educational quality - particularly in poorer regions. We do find strongly increasing returns to schooling that have remained quite stable over time. However, we confirm the finding of low returns to primary education - perhaps associated with quality concerns. Further, the substantial additional gains from completing secondary school are particularly strong for women.

Overall, the growth accounts show that capital deepening has also made small made contributions to growth - despite the recent data revisions that substantially increased in measured investment since 1993. Does the revised data put to rest earlier concerns that investment may be too low, and constraining growth? The data do now show a strongly rising trend for gross investment. However, net investment averaged about 17 percent of GDP during 1999-2004, which we estimate can support an annual growth rate of roughly 7 percent. More rapid growth over the longer term would require an increased investment rate. Notably, the investment increases have been concentrated in the private sector, while public sector investment has fallen steadily as a share of GDP. As discussed below, this is particularly problematic, given concerns about India's weak and deteriorating infrastructure.

We also examine the evolution of India's saving behavior, to explore whether saving is likely to constrain India's investment. We argue that private saving in India has performed remarkably well. The rise is concentrated among households, who now save fully 25 percent of GDP. Further, nearly half household saving is in the form of financial saving, available to fund corporate or public investment. Corporate saving has also risen somewhat over the period. However, public sector saving has been very low historically, 
turning negative during the late 1990s, before recovering somewhat more recently. While not a major focus of this paper, the administrative budget deficit remains a major policy concern. We conclude that saving is not constraining India's growth. There is room for increased public saving, as well as a rise in foreign saving, particularly if financed through FDI which remains quite low in India.

Pulling together the findings of our analysis we draw a number of implications for India's growth in the coming decade. Our starting point is that increasing living standards in India will require a combination of increasing employment and raising labor productivity. To date, the rise in India's output growth has been associated with little or no rise in overall rates of job creation. And while agricultural output has fallen as a share of GDP, agriculture's share of total employment remains surprisingly high. We find that labor productivity in agriculture is just one-fifth that in either industry or services, implying significant productivity gains from further sectoral reallocation of labor.

Thus, India needs to broaden the base of its economic growth through greater efforts to promote the expansion of the industrial sector - especially manufacturing - and to emphasize the creation of jobs as well as gains in TFP. In this context, China provides a useful model, in its use of exports manufactured under foreign contract as a primary driver for growth. One key attraction to this strategy is that it provided rapidly expanding employment opportunities for relatively young, and low-skilled, workers. A second is that it generated large feedback effects for the domestic economy - both in promoting linkages to the supplying industries (including services) and in developing local expertise for doing business in a global market.

To follow this strategy, India needs to create a more attractive economic environment for doing business - a location able to compete effectively with China. This will require strengthening its infrastructure - including a weak and unreliable power system, and poor land transportation in many states. However, compared with China, India already enjoys relative good institutions and is strong in the areas of finance and business services.

Finally, we stress that successful implementation of this growth strategy should not be expected to generate rapid TFP growth within the growing sectors. Expansion of 
both industry and services will draw workers out of agriculture. This will generate gains in aggregate TFP from the reallocation of labor to more productivity activities and from reduced labor redundancy in agriculture. Thus, reforms should be directed towards making it easier to expand domestic production, and a creating a more attractive location for foreign producers. We see the prospects for sustaining this broad-based type of high growth in India as strong. 


\section{References}

Acharya, Shankar. 2004. "India’s Growth Prospects Revisited," Economic and Political Weekly (October 9).

Ahluwalia, Monteck. 2002. "Economic Reforms in India Since 1991: Has Gradualism Worked?" Journal of Economic Perspectives, vol 16, no. 3:67-88.

Baier, S. L., G. P. Dwyer Jr., and R. Tamura. 2006. "How Important are Capital and Total Factor Productivity for Economic Growth?” Economic Inquiry, 44(1): 23 - 49.

Banga, Rashmi. 2005. “Critical Issues in India’s Service-Led Growth.” Working paper no. 171, Indian Council for Research on International Economic Relations. (October)

Banga, Rashmi, and Bishwananth Gopldar. 2004. "Contribution of Services to Output Growth and Productivity In Indian Manufacturing: Pre And Post Reforms,” working paper 139, ICRIER.

Barro, Robert, and Jong-Wha Lee. 2000. "International Data on Educational Attainment, Updates and Implications." Working Paper 7911. Cambridge, MA: National Bureau of Economic Research (September).

Baumol, William J. 1967. "Macroeconomics of Unbalanced Growth: The Anatomy of Urban Crises,” American Economic Review, 57(3), June: 415-26.

Bhattarai, Madhusudan and A. Narayanmoorthy. 2003. 'Impact of Irrigation on Rural Poverty in India: An Aggregate Panel-data Analysis', Water Policy 5: 443-458, 2003

Bosworth, Barry. 2005. 'Economic Growth in Thailand: the Macroeconomic Context,' paper prepared for world Bank project on the investment climate, firm competitiveness and growth in Thailand. Available at: http://www.brookings.edu/es/research/projects/develop/develop.htm

Bosworth, Barry, and Susan M. Collins.2003. "The Empirics of Growth: An Update," Brookings Papers on Economic Activity, 2003:1

Buiter, Willem and Urjit Patel. 1992. "Debt, Finances and Inflation: An Application to the Public Finances of India." Journal of Public Economics 47: 171-205.

Central Statistical Organisation. 1989. National Accounts Statistics: Sources and Methods, (New Delhi: Government of India).

. 1999.New Series on National Accounts Statistics (Base Year 1993-94), (New Delhi: Government of India). 
2004. Report of the Working Group on Workforce Estimation for Compilation of National Accounts Statistics with Base Year 1999-2000, (New Delhi: Government of India)

. 2005. National Account Statistics, 2005. (New Delhi: Government of India)

. 2006. New Series on National Accounts Statistics (Base Year 1999-2000), (New

Delhi: Government of India).

Coelli, Tim J. and D. S. Prasada Rao. 2003. "Total Factor Productivity Growth in Agriculture: A Malmquist Index Analysis of 93 Countries," 1980-2000 Working Paper no. 02/2003, Centre for Efficiency and Productivity Analysis, School of Economics, The University of Queensland.

Directorate of Economics \& Statistics.2005. Agricultural Statistics at a Glance, 2004. New Delhi: Ministry of Agriculture. Available at: http://agricoop.nic.in/statatglance2004/AtGlance.pdf

Dholakia, Bakul H. 2002. "Sources of India's Accelerated Growth and the Vision of Indian Economy in 2020." The Indian Economic Journal, Vol. 29 (4): 27-46.

Dollar, david, Giuseppe Iorossi and taye Mengistae. 2002. "Investment Climate and Economic performance: Some Firm level Evidence from India." World Bank Development Research Group, mimeo (May).

Duraisamy, P. 2000. "Changes in Returns to Education in India, 1983-94: By Gender, Age-Cohort and Location," Discussion paper no. 615, Economic Growth Center, Yale University.

Dutta, Puja Vasudeva. 2004. “The Structure of Wages in India, 1983-1999," PRUS Working Paper no 25, Poverty Research Unit of Sussex, University of Sussex.

Easterly, William. 2001. The Elusive Quest for Growth: Economists' Adventures and Misadventures in the Tropics. Cambridge, MA: MIT Press.

Easterly, William, and Ross Levine. 2001. "It's Not Factor Accumulation: Stylized Facts and Growth Models." World Bank Economic Review 15(2): 177-219.

Everson, Robert, Carl Pray, and Mark Rosegrant. 1999. Agricultural Research and Productivity Growth in India. (Washington D.C. International Food Policy Research Institute.

Foster, Andrew D. and Mark R. Rosenzweig. 2004. "Agricultural Productivity growth, Rural Economic Diversity and Economic reforms: India 1970-2000.” Economic Development and Cultural Change. April; 52 (3): 509-542. 
Goldar, Bishwanath. 2004. "Indian Manufacturing: Productivity Trends in Pre- and PostReform Periods,” Economic and Political Weekly November 20: 5033-42.

Goldar, Bishwanath, and Arup Mitra. 2002. "Total Factor Productivity Growth in Indian Industry: a Review of Studies," in B.S. Minhas (editor), National Income Accounts and Data Systems. New Delhi: Oxford University Press: 218-37.

Gordon, Jim and Poonam Gupta. 2004. "Understanding India's Services Revolution.” IMF Working paper WP/ 04/171 (September).

Hallward-Driemeier, Mary. 2005. "Improving the Climate for Investment and Business in South Asia." World Bank mimeo.

Higgins, M. and J.G. Williamson, 1997, “Age Structure Dynamics in Asia and Dependence on Foreign Capital,” Population and Development Review, 23(2):261-293.

Hulten, Charles. 2001. "Total Factor Productivity: A Short Biography," in New Developments in Productivity Analysis, Charles R. Hulten, Edwin R. Dean, and Michael J. Harper, eds., Studies in Income and Wealth, vol. 63, (Chicago: The University of Chicago Press for the National Bureau of Economic Research, Chicago): 1-47.

Janaiah, Aldas, Lalith Achoth and Cynthia Bantilan. 2005. "Has the Green Revolution Bypassed Coarse Cereal? The Indian Experience?" eJADE, Vol 2 (2005), Issue 1: 2033.

Joshi, Vijay and Ian M. D. Little. 2004. India: Macroeconomics and Political Economy. Washington DC: World Bank and Oxford University press: New Delhi: Oxford University Press.

Kapur, Devesh and Pratap Bhanu Mehta. 2004. "Indian Higher Education Reform: From Half-Baked Socialism to Half-Baked Capitalism," CID Working Paper No. 108 (Cambridge: Harvard University).

Klenow, Peter, and Andrés Rodriguez-Clare. 1997. “The Neoclassical Revival in Growth Economics: Has It Gone Too Far?" In National Bureau of Economic Research Macroeconomics Annual 1997, edited by Ben S. Bernanke and Julio Rotemberg. Cambridge, MA: MIT Press. 73-103.

Kochar, Anjini. 2002. "Emerging Challenges for Indian Education Policy.” In Anne O. Krueger, ed. Economic Policy Reforms and the Indian Economy. Chicago: The University of Chicago Press.

Kohli, Atul. 2006. "Politics of Economic growth in India, 1980-2005 - Part I: the 1980s." Economic and Political Weekly, April 1: 1251-1259.

. 2006. "Politics of Economic growth in India, 1980-2005 - Part II: the 1990s and Beyond.” Economic and Political Weekly, April 8: 1361-1370. 
Kolli. Ramesh and S. Hazra. 2005. "Measuring Non-Observed Economy: Practices Followed In Indian National Accounts Statistics." No 5. Paper presented at $8^{\text {th }}$ Meeting of Expert Group on Informal Sector Statistics (March), Nadi, Fiji Islands.

Kremer, Michael, Karthik Muralidharan, Nazmul Chaudhury, Jeffrey Hammer, and F. Halsey Rogers. 2005. "Teacher Absence in India." Journal of the European Economic Association 3 (2-3): 658-667.

Krueger, Anne. 2005 “Comment and Discussion,” Brookings Trade Forum 2005 (2005) 232-238.

Lane, Philip and Gian Maria Milesi-Ferretti. 2006. “The External Wealth of Nations mark II: Revised and Extended Estimates of Foreign Assets and Liabilities, 19702004.” IMF Working Paper WP/06/69 (March).

Loayza, Norman and Rashmi Shankar. 2000. "Private Saving in India." The World Bank Economic Review. Vol. 14, No. 3 (September): 571-94.

Loayza, Norman, Klaus Schmidt-Hebbel, and Luis Serven. 2000. "What Drives Private Saving across the World?" Review of Economics and Statistics, Vol. 82 (August): $165-181$

Mühleisen, Martin. 1997, "Improving India's Saving Performance," IMF Working Paper No. 97/4 (IMF: Washington).

National Sample Survey Organization. 1997. Employment and Unemployment Situation in India, 1993-1994. NSS 50 ${ }^{\text {th }}$ Round, Report No. 409 (New Delhi: Government of India). .2001. Employment and Unemployment Situation in India, 1999-2000. NSS 55 ${ }^{\text {th }}$ Round, Report No. 458 (New Delhi: Government of India).

. 2005. Employment and Unemployment Situation in India, January - June 2004, NSS $60^{\text {th }}$ Round, Report No. 506 (New Delhi: Government of India).

Organization for Economic Cooperation and Development (OECD). 2001. Measuring Productivity: Measurement of Aggregate and Industry-level Productivity Growth. OECD Manual, Paris. Available at: http://www.oecd.org/dataoecd/59/29/2352458.pdf.

Psacharopoulos, George and Patrinos, Harry A., "Returns to Investment in Education: A Further Update" (September 2002). World Bank Policy Research Working Paper No. 2881.

Panagariya, Arvind. 2004. "India in the 1980s and 1990s: A Triumph of Reforms," Economic and Political Weekly, Vol. 39, No. 25:2581-94. 
Patrinos, Harry, Cris Ridao-Cano and Chris Sakellariou. 2004. "Estimating the returns to education: Accounting for heterogeneity in ability." http://www.u-bourgogne.fr/colloqueiredu/posterscom/communications/PatrinosRidaoCanoSakellariou.pdf

Pritchett, Lant. 2001. "Where has all the Education Gone?" World Bank Economic Review 15(3): 367-391.

Psacharopoulos, George, and Harry Patrinos. 2004. "Returns to Investment in Education: A Further Update," Education Economics, Vol. 12, No. 2, pp. 111-134, August

Reddy, Y.V. 2005. "Importance of Productivity in India." Inaugural address given at the Annual Conference of the Indian Economic Association. http://rbidocs.rbi.org.in/rdocs/Speeches/PDFs/67936.pdf

Reserve Bank of India. 2006. Handbook of Statistics on the Indian Economy. Available at: http://www.rbi.org.in/scripts/Statistics.aspx.

Rodrik, Dani, and Arvind Subramanian. 2005. "From "Hindu Growth" to Productivity Surge: The Mystery of the Indian Growth Transition," IMF Staff Papers, vol. 52, No. 2.

. 2004b. "Why India Can Grow at 7 Percent a Year or More," Economic and Political Weekly (April 17).

Rogers, Mark. 2003. "Directly Unproductive Schooling: How country characteristics affect the impact of schooling on growth." Oxford University Department of Economics Discussion Paper \#166 (July). http://www.economics.ox.ac.uk/Research/wp/pdf/paper166.pdf

Saha, V., A. Kar and T. Baskaran. 2004. "Contribution of Informal Sector and Informal Employment in Indian Economy." Paper presented at 7th Meeting of the Expert Group On Informal Sector Statistics New Delhi (February).

Shetty, S.L. 2006. "Revision of National Accounts Statistics: A Welcome Step, Good in Parts," Economic and Policy Weekly (June 10): 2317-26.

Sivasubramonian, Siva. 2004. The Sources of Economic Growth in India, 1950-1 to 1999-2000, New Delhi: Oxford University Press.

Solow, Robert. 1957. "Technical Change and the Aggregate Production Function," Review of Economics and Statistics, 39 (3): 312-20. 
Srinivasan, T.N. 2003a. "The Indian Economy: Current Problems and Future Prospects," Stanford Center for International Development, Working Paper No. 173 (July).

. 2003b. "Indian Economic Reforms: A Stocktaking," Stanford Center for International Development, Working Paper No. 190 (October)

. 2005. "Information-Technology-Enabled Services and India's Growth Prospects," in Susan M. Collins and Lael Brainard (eds.) Brookings trade Forum 2005: Offshoring White-Collar Work." Washington DC: The Brookings Institution: 203-240.

Srinivasan, T.N., and Suresh D. Tendulkar. 2003. Reintegrating India with the World Economy (Washington D.C: Institute of International Economy)

Sundaram, K., and Suresh D. Tendulkar. 2005a. "Trends in Labour and Employment in India, 1983-2003," paper presented for the India LES of the World Bank.

2005b. "Changing Structure of Indian Workforce, Quality of Employment, and Real Earnings, 1983-2000."

Triplett, Jack and Barry Bosworth. 2004. Productivity in the U.S. Services Sector: New Sources of Economic Growth (Washington D.C: the Brookings Institution Press).

Virmani, Arvind .1997. "India: Crises, Reform and Growth,” Economic and Political Weekly, August 9, 1997.

Virmani, Arvind. 2004. "Sources of India's Economic Growth: Trends in Total Factor Productivity," Working paper no. 131, Indian Council for Research on International Economic Relations.

. 2005. "Policy Regimes, Growth and Poverty in India: Lessons of Government Failure and Entrepreneurial Success," Working paper no. 170, Indian Council for Research on International Economic Relations.

Visaria, Pravin. 2002. "Workforce and Employment in India, 1961-94," in B.S. Minhas (editor), National Income Accounts and Data Systems. New Delhi: Oxford University Press: 1-46.

Wallack, Jessica Seddon. 2003. "Structural Breaks in Indian Macroeconomic Data." Economic and Political Weekly, October 11: 4312-4315.

World Bank. 2002. India's Transport sector: The Challenges Ahead, Volume 1. Washington DC: The World Bank. (May). 
. 2004. India: Investment Climate and Manufacturing Industry. Washington DC: The World bank (November).

Wu, Bing Kin, Venita Kaul and Deepa Sankar. 2005. "The Quiet Revolution: How India is achieving universal elementary education," Finance and Development 42:2 (June).

Young, Alwyn. 1995. "The Tyranny of Numbers: Confronting the Statistical Realities of the East Asian Growth Experience," Quarterly Journal of Economics 100: 641-80. 
Table 1. Measures of the Organized and Unorganized Sectors by Industry. 1999-2000 percent

\begin{tabular}{|c|c|c|c|c|}
\hline \multirow[t]{2}{*}{ Industry } & \multirow{2}{*}{$\begin{array}{l}\text { Distribution of } \\
\text { GDP by sector }\end{array}$} & \multicolumn{2}{|c|}{ Percent of sector GDP } & \multirow{2}{*}{$\begin{array}{c}\text { Percent of sector employment } \\
\text { Unorganized } \\
\end{array}$} \\
\hline & & Organized & Unorganized & \\
\hline Agriculture, forestry and fishering & 25.3 & 3.1 & -- & 99.1 \\
\hline Agriculture & 23.2 & 3.2 & -- & 99.2 \\
\hline Forestry and logging & 1.1 & 5.6 & -- & 98.3 \\
\hline Fishing & 1.1 & 0.1 & -- & 98.5 \\
\hline Industry & 25.4 & 62.5 & 37.5 & .. \\
\hline Mining and Quarrying & 2.3 & 91.6 & 8.4 & 90.7 \\
\hline Manufacturing & 14.7 & 60.8 & 39.2 & 97.9 \\
\hline Electricity, gas and water supply & 2.5 & 93.8 & 6.2 & 90.1 \\
\hline Construction $^{1}$ & 5.9 & 41.8 & 58.2 & 85.8 \\
\hline Services & 49.2 & 51.3 & 48.7 &.. \\
\hline Trade & 12.9 & 18.1 & 81.9 & 84.7 \\
\hline Hotel and restaurants & 1.2 & 41.2 & 58.8 & 90.7 \\
\hline Transport and storage & 5.8 & 35.2 & 64.8 & 79.3 \\
\hline Communication & 1.6 & 91.4 & 8.6 & 92.8 \\
\hline Banking and insurance & 5.9 & 90.5 & 9.5 & 88.7 \\
\hline $\begin{array}{l}\text { Real estate, ownership of } \\
\text { dwellings and business services }\end{array}$ & 7.1 & 18.6 & 81.4 & 89.9 \\
\hline Public admininistration and defenc & 6.7 & 100.0 & 0.0 & 0.4 \\
\hline Other services & 8.1 & 69.5 & 30.5 & 87.4 \\
\hline Non-agricultural sector & 74.7 & 56.0 & 44.0 & 88.3 \\
\hline Total $^{2}$ & 100.0 & 42.0 & 32.4 & 95.6 \\
\hline
\end{tabular}

Source: Saha, Kar and Baskaran (2004) and Government of India, Central Statistical Office (2006,February)

1. norganized employment in construction includes casual laborers in the organized sector. 
Table 2. National Accounts Revisions, Benchmark Years 1993-94 and 1999-00

Millions of rupees

\begin{tabular}{|c|c|c|c|c|c|c|c|c|}
\hline \multirow[b]{2}{*}{ Sector } & \multicolumn{4}{|c|}{ 1993-94 GDP by Sector } & \multicolumn{4}{|c|}{ 1999-00 GDP by Sector } \\
\hline & $\begin{array}{c}\begin{array}{c}\text { Share } \\
\text { of Total }\end{array} \\
(1)\end{array}$ & $\begin{array}{c}\begin{array}{c}1980-81 \\
\text { series }\end{array} \\
(2)\end{array}$ & $\begin{array}{c}\begin{array}{c}1993-94 \\
\text { series }\end{array} \\
(3)\end{array}$ & $\begin{array}{c}\text { Percent } \\
\text { Change } \\
(4)\end{array}$ & $\begin{array}{c}\begin{array}{c}\text { Share } \\
\text { of Total }\end{array} \\
(5)\end{array}$ & $\begin{array}{c}\begin{array}{c}1993-94 \\
\text { series }\end{array} \\
(6)\end{array}$ & $\begin{array}{c}\begin{array}{c}1999-00 \\
\text { series }\end{array} \\
(7)\end{array}$ & $\begin{array}{c}\text { Percent } \\
\text { Change } \\
(8)\end{array}$ \\
\hline Agriculture, forestry and fishing & 30.3 & 2,237 & 2,424 & 8.4 & 25.3 & 4,620 & 4,541 & -1.7 \\
\hline Agriculture & 27.9 & 2,063 & 2,231 & 8.2 & 23.2 & 4,224 & 4,153 & -1.7 \\
\hline Forestry and logging & 1.3 & 98 & 102 & 3.9 & 1.1 & 196 & 195 & -0.4 \\
\hline Fishing & 1.1 & 75 & 91 & 20.2 & 1.1 & 200 & 192 & -3.9 \\
\hline Industry & 25.8 & 2,040 & 2,058 & 0.9 & 25.4 & 4,556 & 4,556 & 0.0 \\
\hline Mining and quarrying & 2.5 & 168 & 197 & 17.1 & 2.3 & 413 & 416 & 0.7 \\
\hline Manufacturing & 15.9 & 1,276 & 1,267 & -0.7 & 14.7 & 2,667 & 2,641 & -1.0 \\
\hline Rregistered & 10.4 & 812 & 831 & 2.3 & 9.7 & 1,708 & 1,730 & 1.3 \\
\hline Unregistered & 5.5 & 464 & 436 & -6.0 & 5.1 & 959 & 911 & -5.0 \\
\hline Electricity, gas and water supply & 2.4 & 189 & 190 & 0.5 & 2.5 & 423 & 447 & 5.8 \\
\hline Construction & 5.1 & 407 & 404 & -0.7 & 5.9 & 1,053 & 1,051 & -0.1 \\
\hline Services & 43.9 & 3,051 & 3,508 & 15.0 & 49.2 & 8,443 & 8,826 & 4.5 \\
\hline Trade, hotels and restaurants & 13.9 & 980 & 1,110 & 13.2 & 14.2 & 2,460 & 2,541 & 3.3 \\
\hline Trade & 13.2 & 922 & 1,056 & 14.6 & 12.9 & 2,290 & 2,319 & 1.3 \\
\hline Hotel and restaurants & 0.7 & 59 & 54 & -7.5 & 1.2 & 170 & 223 & 30.7 \\
\hline Transport, storage and communication & 7.3 & 561 & 580 & 3.4 & 7.4 & 1,243 & 1,318 & 6.0 \\
\hline Railways & 1.2 & 96 & 96 & 0.0 & 1.1 & 156 & 195 & 24.8 \\
\hline Transport by other means & 4.8 & 371 & 383 & 3.4 & 4.6 & 819 & 824 & 0.6 \\
\hline Storage & 0.1 & 6 & 6 & 6.9 & 0.1 & 13 & 14 & 13.1 \\
\hline Communication & 1.2 & 88 & 94 & 6.9 & 1.6 & 256 & 284 & 11.3 \\
\hline Finance, insurance, real estate and busin & & & & & & & & \\
\hline services & 11.2 & 671 & 896 & 33.4 & 13.0 & 2,206 & 2,328 & 5.5 \\
\hline Banking and insurance & 5.2 & 436 & 417 & -4.4 & 5.9 & 1,191 & 1,057 & -11.3 \\
\hline Real estate and business services & 6.0 & 236 & 479 & 103.3 & 7.1 & 1,015 & 1,271 & 25.2 \\
\hline Community, social and personal services & 11.5 & 839 & 923 & 10.0 & 14.7 & 2,534 & 2,640 & 4.2 \\
\hline Public administration and defence & 5.4 & 400 & 431 & 7.9 & 6.7 & 1,167 & 1,197 & 2.6 \\
\hline Other services & 6.2 & 439 & 492 & 12.0 & 8.1 & 1,367 & 1,443 & 5.6 \\
\hline Total GDP at factor cost & 100.0 & 7,329 & 7,991 & 9.0 & 100.0 & 17,618 & 17,923 & 1.7 \\
\hline
\end{tabular}


Table 3. Sources of Economic Growth, Total Economy, 1960-2005

Annual percentage rate of change

\begin{tabular}{|c|c|c|c|c|c|c|c|}
\hline \multirow[b]{2}{*}{ Period } & \multirow[b]{2}{*}{ Output } & \multirow[b]{2}{*}{ Employment } & \multirow[b]{2}{*}{$\begin{array}{c}\text { Output per } \\
\text { Worker }\end{array}$} & \multicolumn{4}{|c|}{ Contribution of: } \\
\hline & & & & $\begin{array}{l}\text { Physical } \\
\text { Capital }\end{array}$ & Land & Education & $\begin{array}{c}\text { Factor } \\
\text { Productivity }\end{array}$ \\
\hline \multicolumn{8}{|c|}{ Total Economy } \\
\hline 1960-04 & 4.7 & 2.0 & 2.6 & 1.2 & -0.1 & 0.3 & 1.2 \\
\hline $1960-80$ & 3.4 & 2.2 & 1.3 & 1.0 & -0.2 & 0.2 & 0.2 \\
\hline 1980-04 & 5.8 & 1.9 & 3.8 & 1.4 & 0.0 & 0.4 & 2.0 \\
\hline $1960-73$ & 3.3 & 2.0 & 1.3 & 1.1 & -0.2 & 0.1 & 0.2 \\
\hline $1973-83$ & 4.2 & 2.4 & 1.8 & 0.9 & -0.2 & 0.3 & 0.6 \\
\hline $1983-93$ & 5.0 & 2.1 & 2.9 & 0.9 & -0.1 & 0.3 & 1.7 \\
\hline $1993-99$ & 7.0 & 1.2 & 5.8 & 2.4 & -0.1 & 0.4 & 2.8 \\
\hline 1999-04 & 6.0 & 2.4 & 3.6 & 1.2 & 0.1 & 0.4 & 2.0 \\
\hline
\end{tabular}


Table 4. Sources of Economic Growth, Major Sectors, 1960-2005

Annual percentage rate of change

\begin{tabular}{|c|c|c|c|c|c|c|c|}
\hline \multirow[b]{2}{*}{ Period } & \multirow[b]{2}{*}{ Output } & \multirow[b]{2}{*}{ Employment } & \multirow[b]{2}{*}{$\begin{array}{c}\text { Output per } \\
\text { Worker }\end{array}$} & \multicolumn{4}{|c|}{ Contribution of: } \\
\hline & & & & $\begin{array}{l}\text { Physical } \\
\text { Capital }\end{array}$ & Land & Education & $\begin{array}{c}\text { Factor } \\
\text { Productivity } \\
\end{array}$ \\
\hline \multicolumn{8}{|c|}{ Agriculture } \\
\hline 1960-04 & 2.4 & 1.4 & 1.0 & 0.4 & -0.1 & 0.2 & 0.6 \\
\hline $1960-80$ & 1.9 & 1.8 & 0.1 & 0.2 & -0.2 & 0.1 & -0.1 \\
\hline 1980-04 & 2.8 & 1.0 & 1.8 & 0.5 & -0.1 & 0.3 & 1.1 \\
\hline $1960-73$ & 1.8 & 1.9 & -0.1 & 0.2 & -0.2 & 0.1 & -0.2 \\
\hline 1973-83 & 2.9 & 1.7 & 1.2 & 0.3 & -0.2 & 0.2 & 0.9 \\
\hline 1983-93 & 2.9 & 1.4 & 1.5 & 0.2 & -0.1 & 0.2 & 1.2 \\
\hline 1993-99 & 2.6 & 0.2 & 2.4 & 0.7 & 0.1 & 0.3 & 1.3 \\
\hline 1999-04 & 1.8 & 1.0 & 0.8 & 0.9 & -0.2 & 0.4 & -0.1 \\
\hline \multicolumn{8}{|c|}{ Industry (Inclusive of Manufacturing) } \\
\hline $1960-04$ & 5.6 & 3.3 & 2.3 & 1.6 & & 0.3 & 0.3 \\
\hline $1960-80$ & 4.7 & 3.1 & 1.6 & 1.8 & & 0.3 & -0.4 \\
\hline 1980-04 & 6.4 & 3.5 & 2.9 & 1.6 & & 0.3 & 1.0 \\
\hline $1960-73$ & 4.7 & 2.3 & 2.4 & 2.3 & & 0.2 & -0.1 \\
\hline 1973-83 & 5.2 & 4.5 & 0.7 & 1.1 & & 0.3 & -0.8 \\
\hline 1983-93 & 6.0 & 2.9 & 3.1 & 1.3 & & 0.3 & 1.4 \\
\hline 1993-99 & 6.9 & 2.4 & 4.5 & 3.0 & & 0.5 & 1.0 \\
\hline 1999-04 & 6.4 & 5.5 & 0.9 & -0.1 & & 0.2 & 0.9 \\
\hline \multicolumn{8}{|c|}{ Manufacturing } \\
\hline 1960-04 & 5.7 & 2.6 & 3.1 & 1.8 & & 0.3 & 0.9 \\
\hline $1960-80$ & 4.6 & 2.7 & 2.0 & 1.5 & & 0.3 & 0.2 \\
\hline $1980-04$ & 6.6 & 2.6 & 4.0 & 2.1 & & 0.4 & 1.5 \\
\hline $1960-73$ & 4.9 & 1.5 & 3.4 & 2.1 & & 0.2 & 1.1 \\
\hline $1973-83$ & 5.3 & 4.3 & 1.0 & 1.0 & & 0.4 & -0.3 \\
\hline 1983-93 & 6.0 & 2.1 & 3.9 & 1.3 & & 0.4 & 2.1 \\
\hline 1993-99 & 7.2 & 1.7 & 5.5 & 4.6 & & 0.6 & 0.3 \\
\hline 1999-04 & 6.4 & 4.4 & 2.0 & 0.4 & & 0.3 & 1.4 \\
\hline \multicolumn{8}{|l|}{ Services } \\
\hline 1960-04 & 6.3 & 3.2 & 3.1 & 0.9 & & 0.4 & 1.7 \\
\hline $1960-80$ & 4.9 & 2.8 & 2.0 & 1.1 & & 0.5 & 0.4 \\
\hline $1980-04$ & 7.6 & 3.6 & 4.0 & 0.7 & & 0.4 & 2.9 \\
\hline $1960-73$ & 4.7 & 1.9 & 2.8 & 1.8 & & 0.4 & 0.5 \\
\hline $1973-83$ & 5.3 & 4.2 & 1.0 & 0.0 & & 0.5 & 0.5 \\
\hline 1983-93 & 6.5 & 3.8 & 2.7 & 0.3 & & 0.4 & 2.0 \\
\hline 1993-99 & 10.2 & 3.1 & 7.0 & 1.5 & & 0.5 & 4.9 \\
\hline 1999-04 & 7.8 & 3.5 & 4.4 & 0.9 & & 0.4 & 3.1 \\
\hline
\end{tabular}


Figure 1. Growth in TFP by Major Sector, 1960-2004 Index, $1960=1.0$

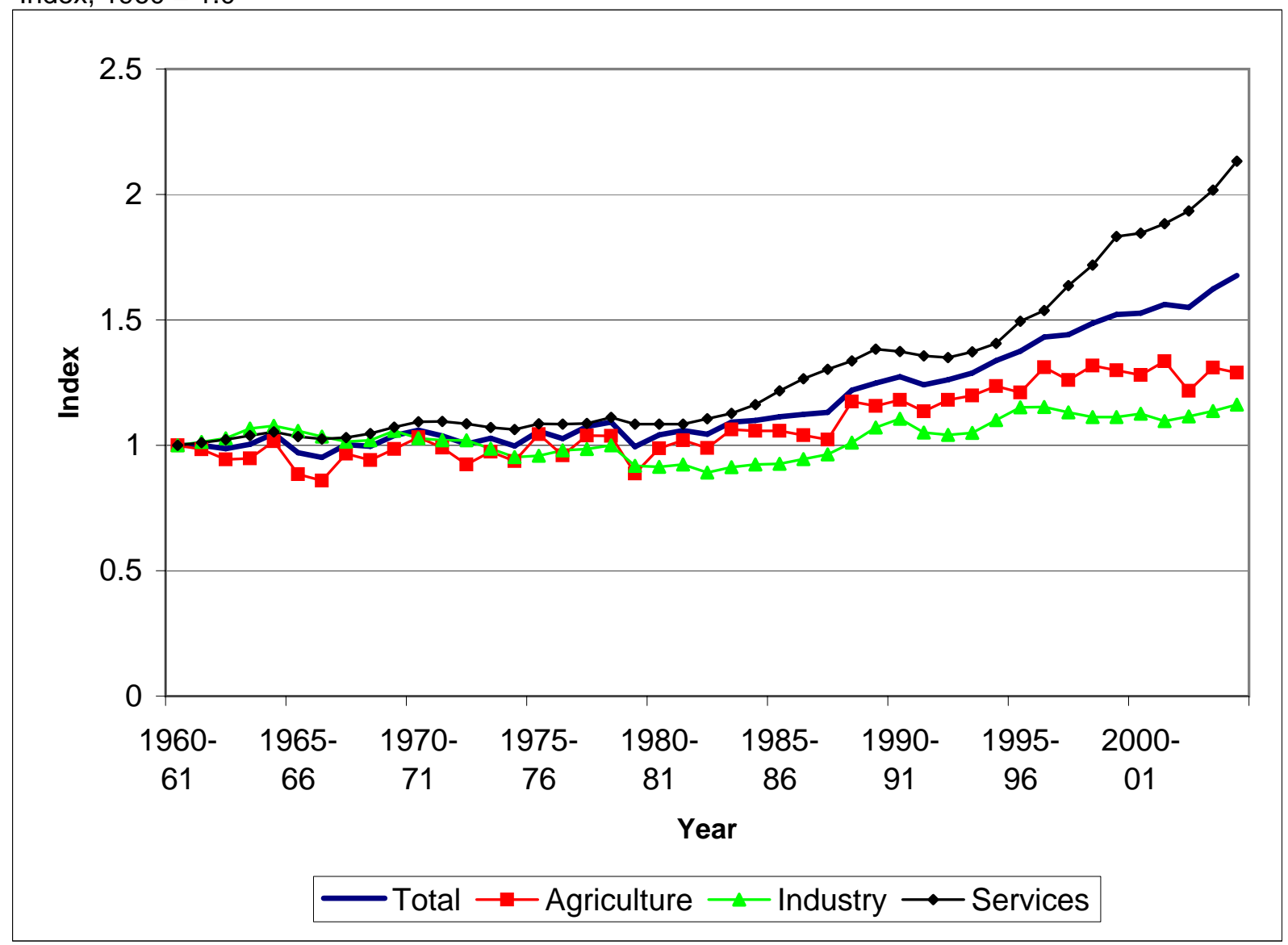

Source: Authors' calculations as described in text. 
Table 5. Growth in Component Service-Producing Industries, 1980-2004 percentage

\begin{tabular}{|c|c|c|c|c|c|c|c|c|c|c|}
\hline \multirow[b]{2}{*}{ Period } & \multicolumn{5}{|c|}{ Modern Services } & \multicolumn{4}{|c|}{ Traditonal Services } & \multirow{2}{*}{$\begin{array}{c}\text { Services } \\
\text { less } \\
\text { Dwellings }\end{array}$} \\
\hline & Total & $\begin{array}{l}\text { Communi } \\
\text { cations }\end{array}$ & Finance & $\begin{array}{l}\text { Business } \\
\text { Services }\end{array}$ & $\begin{array}{l}\text { Education } \\
\text { \& Medical }\end{array}$ & Total & Trade & Transportation & $\begin{array}{c}\text { Other } \\
\text { Services }\end{array}$ & \\
\hline & \multicolumn{10}{|c|}{ Share of Total Output in Services } \\
\hline $1960-61$ & 19 & 2 & 6 & 1 & 10 & 81 & 40 & 14 & 27 & 100 \\
\hline $1980-81$ & 22 & 3 & 7 & 1 & 11 & 78 & 37 & 16 & 24 & 100 \\
\hline 1993-94 & 31 & 3 & 14 & 2 & 12 & 69 & 34 & 14 & 21 & 100 \\
\hline $1999-00$ & 35 & 6 & 14 & 4 & 12 & 65 & 33 & 12 & 19 & 100 \\
\hline \multirow[t]{2}{*}{ 2004-05 } & 40 & 11 & 12 & 5 & 11 & 60 & 33 & 11 & 16 & 100 \\
\hline & \multicolumn{10}{|c|}{ Annual Percentage Rate of Change } \\
\hline $1960-80$ & 5.7 & 6.9 & 5.9 & 3.4 & 5.5 & 4.6 & 4.5 & 5.6 & 4.3 & 4.9 \\
\hline $1980-93$ & 9.0 & 7.1 & 12.3 & 9.8 & 6.6 & 5.4 & 5.6 & 5.4 & 4.9 & 6.3 \\
\hline 1993-99 & 12.6 & 20.3 & 9.3 & 28.0 & 10.6 & 8.9 & 9.8 & 7.5 & 8.6 & 10.1 \\
\hline \multirow[t]{2}{*}{ 1999-04 } & 10.5 & 23.8 & 5.7 & 11.4 & 7.1 & 6.5 & 7.9 & 5.7 & 4.3 & 8.0 \\
\hline & \multicolumn{10}{|c|}{ Percentage Contribution to Total Services Growth } \\
\hline $1960-80$ & 1.1 & 0.1 & 0.3 & 0.0 & 0.5 & 3.8 & 1.8 & 0.8 & 1.2 & 4.9 \\
\hline $1980-93$ & 2.0 & 0.2 & 0.9 & 0.1 & 0.7 & 4.2 & 2.1 & 0.9 & 1.2 & 6.3 \\
\hline 1993-99 & 3.9 & 0.7 & 1.3 & 0.5 & 1.2 & 6.2 & 3.3 & 1.1 & 1.8 & 10.1 \\
\hline 1999-04 & 3.7 & 1.3 & 0.8 & 0.5 & 0.8 & 4.2 & 2.6 & 0.7 & 0.8 & 8.0 \\
\hline
\end{tabular}


Table 6. Growth in Output per Worker, 1960-2005 Sectoral Growth vs. Reallocation Effects

Annual percentage rate of change

\begin{tabular}{cccc}
\hline Period & $\begin{array}{c}\text { Total } \\
\text { Economy } \\
(1)\end{array}$ & $\begin{array}{c}\text { Weighted } \\
\text { Sectoral } \\
\text { Growth } \\
(2)\end{array}$ & $\begin{array}{c}\text { Reallocation } \\
\text { Effects } \\
(1)-(2)\end{array}$ \\
\hline $1960-80$ & 1.3 & 0.9 & 0.4 \\
$1980-04$ & 3.8 & 2.8 & 1.0 \\
$1960-73$ & 1.3 & 1.1 & 0.2 \\
$1973-83$ & 1.8 & 1.0 & 0.8 \\
$1983-93$ & 2.9 & 2.3 & 0.6 \\
$1993-99$ & 5.8 & 4.8 & 1.0 \\
$1999-04$ & 3.6 & 2.4 & 1.2 \\
\hline Authors' & & &
\end{tabular}

Authors' estimates as described in the text. 
Table 7. Educational Attainment of the Total Population Aged 15 and Over, Selected Countries and Years.

Percent

\begin{tabular}{|c|c|c|c|c|c|c|c|}
\hline \multirow[b]{2}{*}{ Country } & \multirow[b]{2}{*}{ Year } & \multicolumn{5}{|c|}{ Highest Level Attained } & \multirow{2}{*}{$\begin{array}{c}\text { Average } \\
\text { Years } \\
\text { of } \\
\text { School }\end{array}$} \\
\hline & & $\begin{array}{c}\text { No } \\
\text { Schooling }\end{array}$ & $\begin{array}{l}\text { Below } \\
\text { Middle }\end{array}$ & Middle & Secondary & $\begin{array}{c}\text { Post } \\
\text { Secondary }\end{array}$ & \\
\hline \multirow[t]{3}{*}{ India } & 1960 & 72.2 & 16.2 & 11.1 & 0.4 & 0.00 & 1.7 \\
\hline & 1980 & 55.0 & 10.0 & 23.9 & 8.6 & 2.61 & 2.9 \\
\hline & 2000 & 40.7 & 9.9 & 27.1 & 16.8 & 5.60 & 4.5 \\
\hline \multirow[t]{3}{*}{ China } & 1960 & & & & & & \\
\hline & 1980 & 34.0 & 19.5 & 35.6 & 10.2 & 0.60 & 4.8 \\
\hline & 2000 & 18.0 & 21.1 & 43.3 & 15.5 & 2.10 & 6.4 \\
\hline \multirow[t]{3}{*}{ Thailand } & 1960 & 36.9 & 12.7 & 47.6 & 2.3 & 0.40 & 4.3 \\
\hline & 1980 & 14.4 & 66.1 & 12.1 & 6.4 & 0.90 & 4.4 \\
\hline & 2000 & 12.6 & 34.5 & 37.9 & 8.1 & 7.00 & 6.5 \\
\hline \multirow[t]{3}{*}{ Malaysia } & 1960 & 49.7 & 25.0 & 20.5 & 3.6 & 1.10 & 2.9 \\
\hline & 1980 & 26.8 & 22.2 & 41.0 & 8.8 & 1.10 & 5.1 \\
\hline & 2000 & 16.2 & 16.4 & 48.7 & 15.8 & 2.90 & 6.8 \\
\hline \multirow[t]{3}{*}{ Indonesia } & 1960 & 68.0 & 16.8 & 14.5 & 0.8 & 0.00 & 1.6 \\
\hline & 1980 & 31.9 & 33.0 & 29.3 & 5.7 & 0.10 & 3.7 \\
\hline & 2000 & 32.1 & 18.2 & 36.7 & 12.4 & 0.50 & 5.0 \\
\hline
\end{tabular}

Source: Barro and Lee (2000), NSSO various years, and authors' calculations.

Note: Data for India in 1980 and 2000 come from the surveys conducted in 1983-84 and 1999-2000, respectively. 
Table 8. Educational Attainment of Workers Aged 15-64

percent

\begin{tabular}{|c|c|c|c|c|c|}
\hline Schooling Level & 1960 & $1983-84$ & 1993-94 & $1999-00$ & 2004 \\
\hline Illiterate & 72.2 & 56.6 & 48.5 & 43.5 & 39.4 \\
\hline Below Primary & \multirow{2}{*}{16.2} & 11.1 & 12.0 & 11.0 & 9.1 \\
\hline Primary & & 12.8 & 11.9 & 11.7 & 14.5 \\
\hline Middle & 11.1 & 9.6 & 11.8 & 14.1 & 17.1 \\
\hline Secondary & \multirow{2}{*}{0.4} & \multirow{2}{*}{7.2} & 7.5 & 9.3 & 8.9 \\
\hline Higher Secondary & & & 3.7 & 4.5 & 5.1 \\
\hline Graduate & 0.0 & 2.7 & 4.5 & 5.9 & 6.0 \\
\hline
\end{tabular}

Source: NSSO (various years), and authors' calculations.

Note: Data for 1960 reflect educational attainment of all persons $15+$. 
Table 9. Regressions of Wages on Educational Attainment, 1983-2004

\begin{tabular}{|c|c|c|c|c|}
\hline \multirow[b]{2}{*}{ Coefficient } & \multicolumn{4}{|c|}{ Survey Round } \\
\hline & $\begin{array}{c}\# 38 \\
(1983) \\
\end{array}$ & $\begin{array}{c}\# 50 \\
(1993-94) \\
\end{array}$ & $\begin{array}{c}\# 55 \\
(1999-2000) \\
\end{array}$ & $\begin{array}{c}\# 60 \\
(2004) \\
\end{array}$ \\
\hline Below Primary & 0.19 & 0.21 & 0.22 & 0.24 \\
\hline Primary & 0.31 & 0.33 & 0.35 & 0.34 \\
\hline Middle & 0.55 & 0.52 & 0.52 & 0.54 \\
\hline Secondary & & 0.91 & 0.92 & 0.78 \\
\hline Higher Secondary & 1.02 & 1.07 & 1.14 & 1.01 \\
\hline Diploma Certificate & & & & 1.32 \\
\hline Graduate & 1.39 & 1.37 & 1.52 & 1.47 \\
\hline Tech Degree & & & 0.51 & 0.51 \\
\hline Tech Certificate & 0.29 & 0.27 & 0.30 & 0.25 \\
\hline Female & -0.53 & -0.44 & -0.44 & -0.46 \\
\hline Rural & -0.44 & -0.33 & -0.41 & -0.45 \\
\hline Constant & 8.44 & 9.27 & 5.38 & 5.52 \\
\hline $\operatorname{adj} \_R^{2}$ & 0.50 & 0.40 & 0.54 & 0.50 \\
\hline RMSE & 0.70 & 0.86 & 0.69 & 0.72 \\
\hline Sample size & 87,769 & 81,038 & 88,430 & 42,501 \\
\hline \multicolumn{5}{|c|}{$\begin{array}{l}\text { Source: Government of India, National Sample Survey Organization, various } \\
\text { years and authors' calculations. } \\
\text { Note: Sample includes all persons aged } 15 \text { to } 64 \text { who reported positive } \\
\text { wages during the reference week. The dependent variable is the log of the } \\
\text { weekly wage. Regressions also included categorical variables for sub-round } \\
\text { and ten-year age brackets (not shown). The excluded education category is } \\
\text { illiterates. All coefficients shown are significant at the } .0001 \text { probability level } \\
\text { or higher. }\end{array}$} \\
\hline
\end{tabular}

Table 10. Implied Incremental Rates of Return by Schooling Level percent

\begin{tabular}{lcccc}
\hline & \multicolumn{4}{c}{ Survey Round } \\
\cline { 2 - 5 } Schooling Level & $\# 38$ & $\# 50$ & $\# 55$ & $\# 60$ \\
Below Primary & $(1983)$ & $(1993-94)$ & $(1999-2000)$ & $(2004)$ \\
Primary & 6.3 & 7.3 & 7.6 & 8.0 \\
Middle & 4.3 & 3.9 & 4.0 & 3.4 \\
Secondary & 5.4 & 4.2 & 3.8 & 4.5 \\
Higher Secondary & 10.5 & 14.9 & 15.4 & 9.2 \\
Graduate & 4.3 & 4.0 & 5.5 & 6.3 \\
\hline
\end{tabular}

Computed from the coefficients in table 9: the proportionate change in the coefficient of progressively higher levels of education expressed as an annual rate. 
Figure 2a. Gross National Saving by Sector, 1970-2004

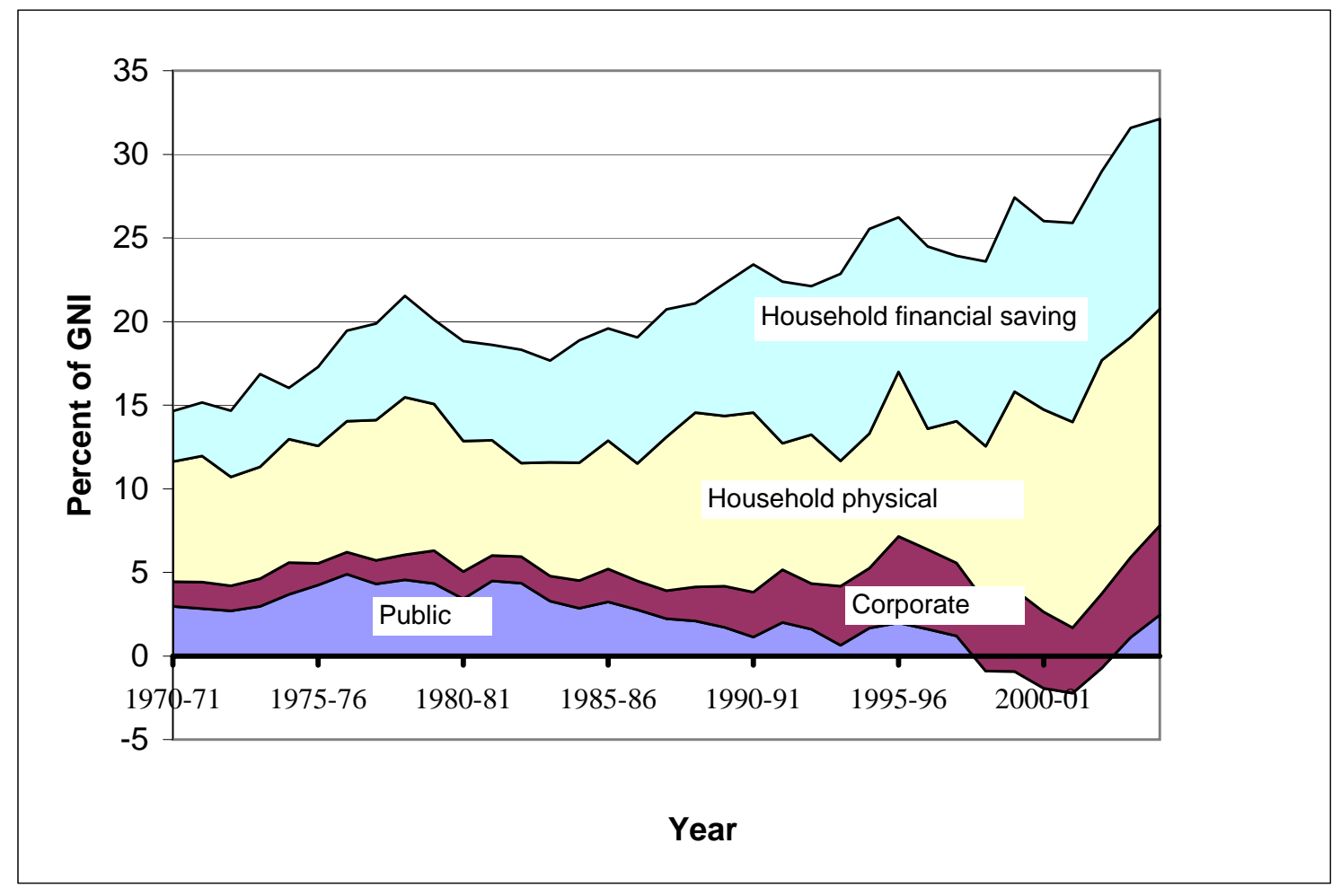

Figure 2b. Capital Formation by Sector, 1970 -2004

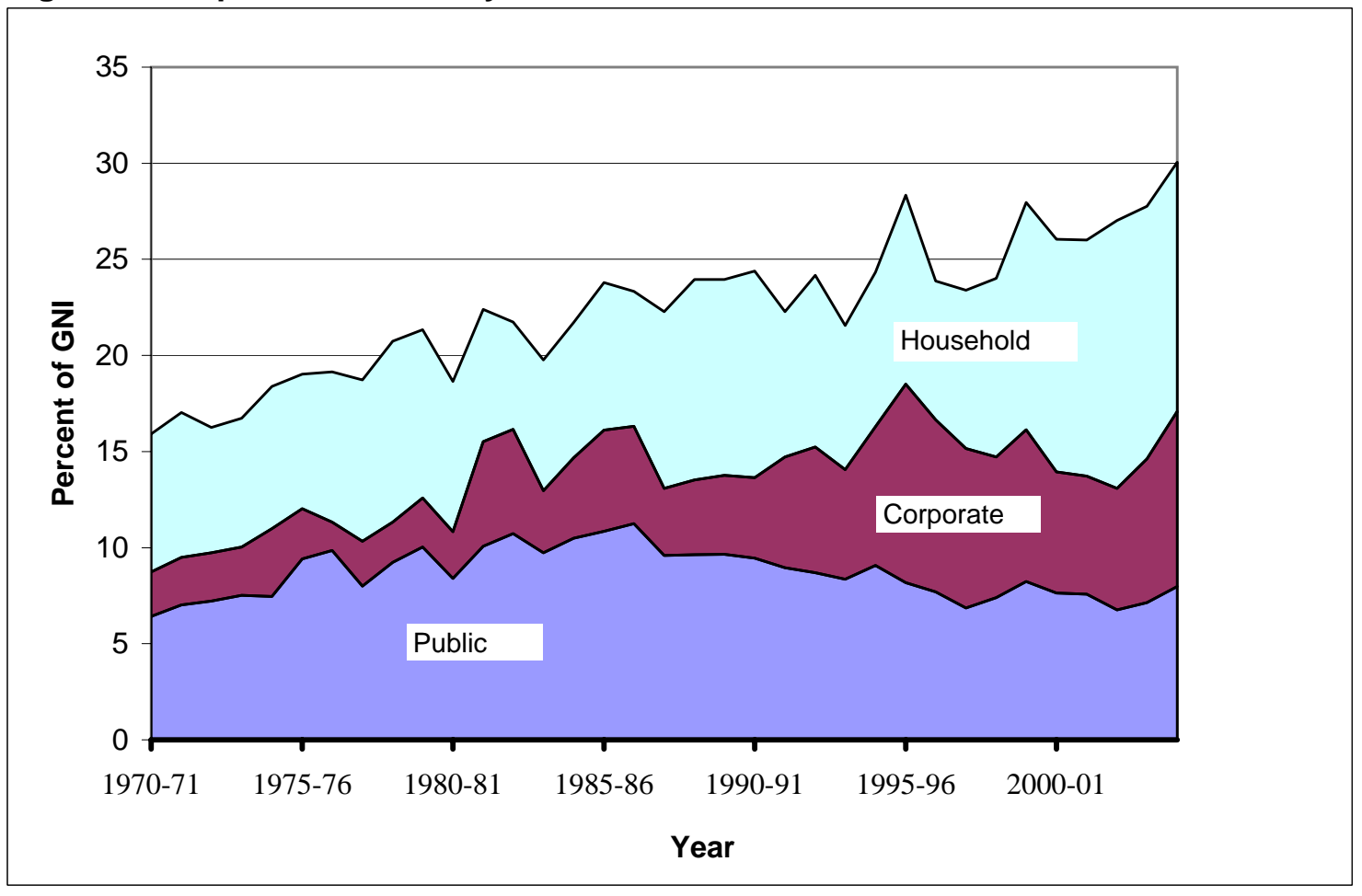

Source: See appendix table 2. 
Table 11. Saving and Investment of the Public Sector, 1970-2004

percent of GNI

\begin{tabular}{lcccccc}
\hline & $1970-79$ & $1980-84$ & $1985-89$ & $1990-94$ & $1995-99$ & $2000-04$ \\
\hline Public sector saving & 3.7 & 3.7 & 2.4 & 1.4 & 0.6 & -0.3 \\
$\quad$ Administration & 2.0 & 1.4 & -1.2 & -2.0 & -3.3 & -5.1 \\
$\quad$ Other public & 1.7 & 2.3 & 3.6 & 3.4 & 3.9 & 4.8 \\
& & & & & & \\
Public sector investment & 8.2 & 9.9 & 10.2 & 8.9 & 7.7 & 7.4 \\
$\quad$ Administration & 1.4 & 1.6 & 1.6 & 1.4 & 1.2 & 2.0 \\
$\quad$ Other public & 6.8 & 8.3 & 8.6 & 7.5 & 6.2 & 5.5 \\
& & & & & & \\
Puiblic sector net lending & -4.5 & -6.2 & -7.8 & -7.5 & -7.1 & -7.7 \\
$\quad$ Administration & 0.6 & -0.2 & -2.8 & -3.3 & -4.5 & -7.0 \\
$\quad$ Other public & -5.1 & -6.0 & -5.0 & -4.2 & -2.3 & -0.6 \\
$\quad$ & & & & & & \\
Addenda: & & & & & & \\
$\quad$ Infrastructure investment & 4.2 & 4.8 & 5.5 & 5.6 & 5.2 & 5.7 \\
\hline Source: appendix table & & & & &
\end{tabular}

Source: appendix table 1.

note: Infrastucture investment includes investment of public utilities and the transportation and

communication industries.

Table 12. Nominal and Real Lending Rates, 1970-2004

\begin{tabular}{lrrrrrrr}
\hline Year & $1970-74$ & $1975-79$ & $1980-84$ & $1985-89$ & $1990-94$ & $1995-99$ & $2000-04$ \\
\hline & & & & & & & \\
Nominal lending rate & 9.0 & 10.4 & 13.3 & 13.9 & 16.7 & 15.2 & 11.4 \\
Inflation rate & 15.3 & 4.7 & 9.3 & 6.7 & 11.0 & 5.3 & 5.2 \\
Real interest rate & -4.9 & 5.9 & 3.9 & 6.8 & 5.2 & 9.4 & 5.9 \\
\hline
\end{tabular}

Source: Reserve Bank of India(2006), tables 70 and 169.

The nominal lending rate is an average of the rates for four major lending institutions. The inflation rate is measured by the annual rate of change in the wholesale price index for all commodities. 


\section{Appendix 1. Data Used to Compute Workforce, 1973-04}

\begin{tabular}{|c|c|c|c|c|c|}
\hline \multirow{3}{*}{ round } & \multirow{3}{*}{ date } & \multicolumn{4}{|c|}{ usually employed } \\
\hline & & \multicolumn{2}{|c|}{ male } & \multicolumn{2}{|c|}{ female } \\
\hline & & ps & all & ps & all \\
\hline & & \multicolumn{4}{|c|}{$\begin{array}{c}\text { Worker participation rates, per } 1000 \text { persons } \\
\text { rural }\end{array}$} \\
\hline 27 & 1-Apr-73 & & 545 & & 318 \\
\hline 32 & 1-Jan-78 & 537 & 552 & 248 & 331 \\
\hline 38 & 1-Jul-83 & 528 & 547 & 248 & 340 \\
\hline 43 & 1-Jan-88 & 517 & 539 & 245 & 323 \\
\hline 50 & 1-Jan-94 & 538 & 553 & 234 & 328 \\
\hline 55 & 1-Jan-00 & 522 & 531 & 231 & 299 \\
\hline \multirow[t]{2}{*}{60} & 1-Mar-04 & 527 & 542 & 228 & 315 \\
\hline & & \multicolumn{4}{|c|}{ urban } \\
\hline 27 & 1-Apr-73 & & 501 & & 134 \\
\hline 32 & 1-Jan-78 & 497 & 508 & 123 & 156 \\
\hline 38 & 1-Jul-83 & 500 & 512 & 120 & 151 \\
\hline 43 & 1-Jan-88 & 496 & 506 & 118 & 152 \\
\hline 50 & 1-Jan-94 & 513 & 521 & 121 & 155 \\
\hline 55 & 1-Jan-00 & 513 & 518 & 117 & 139 \\
\hline \multirow[t]{4}{*}{60} & 1-Mar-04 & 531 & 518 & 121 & 150 \\
\hline & & \multicolumn{4}{|c|}{ Population (millions) } \\
\hline & & \multicolumn{2}{|c|}{ rural } & \multicolumn{2}{|c|}{ urban } \\
\hline & & male & female & male & female \\
\hline 27 & 1-Apr-73 & 233.6 & 221.7 & 63.3 & 54.6 \\
\hline 32 & 1-Jan-78 & 254.4 & 241.7 & 75.6 & 65.9 \\
\hline 38 & 1-Jul-83 & 280.6 & 266.0 & 91.1 & 80.4 \\
\hline 43 & 1-Jan-88 & 305.5 & 287.9 & 104.4 & 92.8 \\
\hline 50 & 1-Jan-94 & 339.4 & 319.4 & 124.0 & 111.1 \\
\hline 55 & 1-Jan-00 & 374.4 & 353.8 & 145.9 & 131.2 \\
\hline \multirow[t]{4}{*}{60} & 1-Mar-04 & 396.8 & 375.2 & 161.6 & 145.5 \\
\hline & & \multicolumn{4}{|c|}{ Workforce (millions) } \\
\hline & & \multicolumn{2}{|c|}{ rural } & \multicolumn{2}{|c|}{ urban } \\
\hline & mid round & male & female & male & female \\
\hline 27 & 1-Apr-73 & 127.3 & 70.5 & 31.7 & 7.3 \\
\hline 32 & 1-Jan-78 & 140.4 & 80.0 & 38.4 & 10.3 \\
\hline 38 & 1-Jul-83 & 153.5 & 90.5 & 46.6 & 12.1 \\
\hline 43 & 1-Jan-88 & 164.7 & 93.0 & 52.8 & 14.1 \\
\hline 50 & 1-Jan-94 & 187.7 & 104.8 & 64.6 & 17.2 \\
\hline 55 & 1-Jan-00 & 198.8 & 105.8 & 75.6 & 18.2 \\
\hline 60 & 1-Mar-04 & 215.0 & 118.2 & 83.7 & 21.8 \\
\hline
\end{tabular}


Appendix 2. Components of Saving and Invesment Balance, 1960-2004

\begin{tabular}{|c|c|c|c|c|c|c|c|c|c|c|c|c|}
\hline Year & $1960-79$ & $1970-79$ & $1980-84$ & $1985-89$ & $1990-94$ & $1995-99$ & $2000-04$ & $2000-01$ & $2001-02$ & $2002-03$ & $2003-04$ & 2004-05 \\
\hline Gross domestic saving & 15.1 & 17.6 & 18.5 & 20.5 & 23.3 & 25.3 & 28.9 & 26.0 & 25.9 & 29.0 & 31.6 & 32.1 \\
\hline Household Sector & 10.4 & 12.3 & 13.2 & 16.2 & 18.7 & 19.9 & 24.6 & 23.4 & 24.2 & 25.3 & 25.7 & 24.3 \\
\hline Financial savings & 3.7 & 4.6 & 6.4 & 7.3 & 10.2 & 10.5 & 11.7 & 11.3 & 11.9 & 11.3 & 12.5 & 11.4 \\
\hline Physical savings & 6.7 & 7.7 & 6.8 & 8.9 & 8.6 & 9.3 & 12.9 & 12.1 & 12.3 & 13.9 & 13.2 & 13.0 \\
\hline Private corporate sector & 1.5 & 1.6 & 1.6 & 2.0 & 3.1 & 4.7 & 4.6 & 4.6 & 3.9 & 4.5 & 4.8 & 5.3 \\
\hline Public Sector & 3.3 & 3.7 & 3.7 & 2.4 & 1.4 & 0.6 & -0.3 & -1.9 & -2.2 & -0.7 & 1.1 & 2.5 \\
\hline Administration & 1.7 & 2.0 & 1.4 & -1.2 & -2.0 & -3.3 & -5.1 & -6.1 & -6.6 & -5.7 & -4.0 & -3.0 \\
\hline Other & 1.6 & 1.7 & 2.3 & 3.6 & 3.4 & 3.9 & 4.8 & 4.1 & 4.4 & 5.0 & 5.1 & 5.4 \\
\hline External Investment (current ac & -1.1 & -0.1 & -1.4 & -2.4 & -1.5 & -1.4 & 0.4 & -0.7 & 0.7 & 1.3 & 1.8 & -1.1 \\
\hline Total capital formation & 16.2 & 17.7 & 19.8 & 22.9 & 24.8 & 26.6 & 28.5 & 26.7 & 25.2 & 27.7 & 29.8 & 33.2 \\
\hline Errors and Omissions & -0.7 & -0.6 & -1.0 & -0.6 & 1.4 & 1.1 & 1.2 & 0.6 & -0.8 & 0.7 & 2.0 & 3.2 \\
\hline Unadjusted capital formation & 16.9 & 18.3 & 20.9 & 23.5 & 23.3 & 25.5 & 27.4 & 26.0 & 26.0 & 27.0 & 27.8 & 30.0 \\
\hline Public sector & 7.6 & 8.2 & 9.9 & 10.2 & 8.9 & 7.7 & 7.4 & 7.6 & 7.6 & 6.8 & 7.1 & 8.0 \\
\hline Administration & 1.4 & 1.4 & 1.6 & 1.6 & 1.4 & 1.2 & 2.0 & 1.8 & 1.6 & 1.9 & 2.1 & 2.4 \\
\hline Other public & 6.2 & 6.8 & 8.3 & 8.6 & 7.5 & 6.2 & 5.5 & 5.9 & 6.0 & 4.8 & 5.0 & 5.6 \\
\hline Private crporate sector & 2.6 & 2.4 & 4.1 & 4.4 & 5.9 & 8.6 & 7.1 & 6.3 & 6.1 & 6.3 & 7.5 & 9.1 \\
\hline Household sector & 6.7 & 7.7 & 6.8 & 8.9 & 8.6 & 9.3 & 12.9 & 12.1 & 12.3 & 13.9 & 13.2 & 13.0 \\
\hline Valuables & & & & & 0.1 & 0.4 & 0.9 & 0.8 & 0.7 & 0.6 & 1.0 & 1.4 \\
\hline Industry basis & 17.3 & 18.8 & 22.6 & 23.8 & 22.1 & 27.3 & 27.4 & 26.0 & 26.0 & 27.0 & 27.8 & 30.0 \\
\hline Ariculture & 34.0 & 25.2 & 17.4 & 12.1 & 7.9 & 8.6 & 5.1 & 5.4 & 3.6 & 4.9 & 5.4 & 6.1 \\
\hline Industry & 0.0 & 0.0 & 0.0 & 0.0 & 0.0 & 0.0 & 0.0 & 0.0 & 0.0 & 0.0 & 0.0 & 0.0 \\
\hline Services & 17.3 & 18.8 & 22.6 & 23.8 & 22.1 & 28.1 & 27.4 & 26.0 & 26.0 & 27.0 & 27.8 & 30.0 \\
\hline Real estate & 2.4 & 2.7 & 2.6 & 2.2 & 2.0 & 2.4 & 2.6 & 2.4 & 2.9 & 2.8 & 2.6 & 2.4 \\
\hline Capital consumption allowances & 6.7 & 7.3 & 8.9 & 9.7 & 9.9 & 10.4 & 10.5 & 10.6 & 10.6 & 10.5 & 10.2 & 10.4 \\
\hline Infrastucture Investment & 4.1 & 4.2 & 4.8 & 5.5 & 5.6 & 5.2 & 5.7 & 6.1 & 5.2 & 5.5 & 5.4 & 6.2 \\
\hline Fixed Investment - asset & 15.0 & 15.9 & 19.1 & 21.6 & 22.6 & 24.6 & 26.5 & 25.1 & 25.4 & 26.3 & 27.0 & 28.6 \\
\hline Fixed investment - industry & 15.4 & 16.3 & 20.8 & 22.0 & 22.6 & 26.6 & 26.5 & 25.1 & 25.4 & 26.3 & 27.0 & 28.6 \\
\hline
\end{tabular}

Source: CSO (2006) and prior years.

Data include the revisions publised in the $1999-00$ base year revisions, but total capital formation redefined to exclude valuables. 